\title{
The Constitutionality of State Laws Providing Employment Leave for Pregnancy: Rethinking Geduldig After Cal Fed
}

\author{
Wendy S. Strimling $\dagger$
}

\section{INTRODUCTION}

In the Umited States today, a majority of women of reproductive age work outside the home, ${ }^{1}$ yet employment policy is only just beginning to adjust to their presence. Employment policy remains largely predicated on the model of a single-earner family organized according to a sexual division of labor whereby a husband earns wages and a wife bears and cares for children. Although this model accurately describes only a small proportion of households, ${ }^{2}$ few employment laws require employers to accommodate the needs of a varied work force that includes mothers simgly responsible for supporting and raising children, pregnant and childbearing women, and fathers responsible for childrearing. Some states, however, have begun to enact legislation based on the recognition that a substantial proportion of employees will become pregnant at some time during their working lives. These states have passed laws requiring employers to provide a leave of absence to women for pregnancy or childbirth. ${ }^{3}$

Pregnancy-leave laws raise controversial questions for feminists advocatimg gender equality and for courts enforcing constitutional and statutory mandates of equality. The controversy stems from the fact that

$\dagger$ B.A. 1978, University of California, Santa Cruz; M.S. 1981, University of Wisconsin, Madison; J.D. 1988, Boalt Hall School of Law, University of California, Berkeley.

1. In 1986, 54.7\% of wonıen over age 16 were in the civilian labor force. BUREAU OF THE Census, U.S. Dep't of Commerce, Statistical AbSTRact of the United States: 1988 No. 623 , at 373 (1988). Among wonien of prime reproductivc age in 1986, 72.4\% of those age 20 to 24, $71.6 \%$ of those age 25 to 34 , and $73.1 \%$ of those age 35 to 44 were in the civilian labor force. Id. No. 608 , at 366 .

2. In 1985, among households with children under 18 years old and with both spouses present, $61.0 \%$ of wives were in the labor force. Id. No. 625, at 374. Of households with children under 18 years old present, over $22 \%$ were headed by single parents, usually by a single inother. Id. No. 68 , at 49 .

3. See, e.g., CaL. Gov'T CODE $\S 12945(b)(2)$ (West 1980); CONN. GEN. STAT. ANN. $§ 46 a-$ 60(a)(7)(B) (West 1986); Iowa CoDE ANN. $§ 601$ A.6.2.e (West 1988); Mass. GeN. LAws ANN. ch. 149, § 105D (West Supp. 1988); MONT. CODE ANN. § 49-2-310(2) (1987); TENN. CodE ANN. $\S 421-408$ (Supp. 1988) (amending $§ \S 50-1-501$ to -505 (Supp. 1987)). 
these laws explicitly treat women and men differently on the basis of biological difference, requiring employers to provide a leave of absence to women for pregnancy regardless of whetlier employers provide leave to men for disability.

Feminists have disagreed about whether this different treatment promotes or detracts from gender equality resulting in tlie so-called "equal treatment/special treatment" debate. ${ }^{4}$ If equal treatment is defined as identical treatment without regard to biological difference, laws that compel different treatment of women and men based on biological difference perpetuate inequality by reinforcing tlie stereotype that women's capacity to give birtli makes tliem less serious, less dependable workers. However, if the measure of equality is equal outcome, employment leave for pregnancy lielps restructure the workplace to accommodate women as well as men. By providing leave for pregnancy disability or childbirth, these laws provide women witlı the opportumity, already available to men, to liave children without fear of losimg tlieir jobs or sacrificing seniority.

The debate over state-required pregnancy leave ultinately centered on two cases before the Umited States Supreme Court. In Miller-Wohl Co. v. Commissioner of Labor \& Industry, ${ }^{5}$ an employer challenged a Montana statute that required it to grant women a leave of absence for pregnancy. The employer alleged that the statute denied women and men equal protection in violation of the fourteentli amendment of the United States Constitution. ${ }^{6}$ The employer also argued that the Montana statute was preempted by a federal statute, title VII of the Civil Riglits Act of $1964 .^{7}$ As amended by the Preguancy Discrimination Act (PDA) of 1978, title VII prohibits employers from discriminating on the basis of sex, including discriminating on the basis of preguancy. ${ }^{8}$

4. The feminist debate is discussed infra at notes 108-121 and accompanying text.

5. 107 S. Ct. 919 (1987), vacating 214 Mont. 238, 692 P.2d 1243 (1984).

6. The fourteenth amendment provides that "[n]o state shall ... deny to any person within its jurisdiction the equal protection of the laws." U.S. CONST. amend. XIV, $\S 1$.

7. Title VII of the Civil Rights Act of 1964 prohibits employers from discriminating on the basis of sex. 42 U.S.C. $\$ 2000$ e-2a (1982). Section 2000e-2(a) provides in relevant part:

It shall be an unlawful einployment practice for an employer-

(1) to fail or refuse to hire or to discharge an individual, or otherwise to discriminate against any individual with respect to his coinpensation, terms, conditions, or privileges of employinent, because of such individual's race, color, religion, sex, or national origin; or

(2) to limit, segregate, or classify his employees ... in any way which would deprive or tend to deprive any individual of employinent opportunities or otherwise adversely affect his status as an employee, because of such individual's race, color, religion, sex, or national origin.

8. In 1978, Congress passed the Pregnancy Discrimination Act (PDA), aniending the definitional seetion of title VII to clarify that pregnancy discrionination is within the definition of sex discrimination for the purposes of the statute. 42 U.S.C. $\$ 2000 \mathrm{e}(\mathrm{k})$ (1982). The PDA provides in pertinent part:

The terms "because of sex" or "on the basis of sex" include, but are not limited to, because 
The second case, California Federal Savings \& Loan Association v. Guerra, ${ }^{9}$ involved an employer's challenge to a California statute that requires employers to provide female employees with a leave of absence for disability resulting from pregnancy or childbirth. The employer challenged the statute solely on the grounds that it conflicted with-and was thus preempted by-title VII.

The Court's 1987 rulings on the two cases provided ouly a partial judicial framework for evaluating whether different treatment based on biological difference constitutes equal treatment. In $\mathrm{Cal} \mathrm{Fed,} \mathrm{the} \mathrm{Court}$ upheld the California statute. Holding that title VII did not preempt the California statute, the Court examined the impact of the pregnancy-leave statute on women and concluded that the narrowly drafted leave provision served the goal of gender equality. ${ }^{10}$

The Court stopped short of extending this analysis to equal protection doctrine, however. Instead, the Court ignored the constitutional question im Miller-Wohl entirely, and merely remanded Miller-Wohl in hight of Cal Fed. "Whether pregnancy-leave statutes are constitutional, then, remains an open question.

Moreover, by skirting the constutional question, the court avoided reconsidernig existing equal protection analysis of laws governing pregnancy. A inuch criticized decision, Geduldig v. Aiello, ${ }^{12}$ remains the Court's last word on whether laws governing einployinent benefits for pregnancy deny equal protection of women and men. In Geduldig, the Court concluded that because pregnancy is a unique physical condition, the legal treatinent of it has no bearing on gender equality. ${ }^{13}$ The Court's biologistic reasoning fails to acknowledge that society's treatment of pregnancy affects gender equality. Consequently, the current equal protection framework contains no basis for evaluating whether a law governing pregnancy denies equal treatment to women and men.

If the constitutional guarantee of equal protection is to have meaning for childbearing women who work outside the home, the Suprente Court cannot afford to avoid the equality issues raised by the pregnancyleave statutes. Equal protection doctrine needs soine working under-

of or on the basis of pregnancy, childbirth, or related medical conditions; and women affected by pregnancy, childbirth, or related medical conditions shall be treated the same for all employment-related purposes, including receipt of benefits under fringe benefit programs, as other persons not so affected but similar in their ability or inability to work

....

9. 107 S. Ct. 683 (1987).

10. Id. at 694 .

11. 107 S. Ct. 919 (1987).

12. 417 U.S. 484 (1974). As one scholar has noted, criticism of Geduldig has become "a cottage industry." Law, Rethinking Sex and the Constitution, 132 U. PA. L. REv. 955, 983 (1984). For a list of law review articles criticizing the decision, see id. at 983 n.107.

13. 417 U.S. at 496 n.20. 
standing of the meaning of equal treatment in order to determine whether equal protection requires identical treatment of woinen and men without regard to biological difference or, alternatively, accommodation of biological difference.

Equal protection doctrine must be revised, beginning with an acceptance of the premise that society's treatment of pregnancy affects gender equality. Title VII of the Civil Rights Act of 1964 incorporated this premise over a decade ago when Congress passed the Pregnancy Discrimination Act, clarifying that pregnancy discrimination constitutes sex discrimination under the statute. ${ }^{14}$ Equal protection jurisprudence must similarly recognize that a law that differentiates on the basis of pregnancy represents a gender-based classification.

Once laws governing pregnancy are categorized as gender classifications, such laws should receive the same intermediate level of scrutiny to which all gender classifications are presently subject. ${ }^{15}$ While this revision does not require the Court to abandon its current equal protection framework for analyzing gender-based laws, the Court would need to alter its underlying analysis of the significance of biological difference for gender equality. In $\mathrm{Cal} \mathrm{Fed}$, the Court evaluated a pregnancy-leave statute by examining its consequences for women. The Court should adopt a similar approach when scrutinizing a pregnancy-based law to determine if it denies equal protection.

Rejecting the extreme positions that biological difference either always or never justifies different treatnient, Cal Fed suggests a niore subtle approach whereby the social impact of the law, rather than the mere fact that it classifies by pregnancy, would determine whether it violates the equal protection guarantee. The result would be neither to validate nor invalidate all state laws that provide wonien with employment leave for pregnancy and childbirth. Rather, the intermediate scrutiny standard would be capable of distinguishing gender-based classifications that rest on disadvantaging stereotypes from those that rest on wonien's physical needs arising froin pregnancy and childbirth. A court applying this standard would uphold a pregnancy-based law only if the statute's different treatment of women and nien was narrowly circuniscribed so as to contribute to social and economic gender equality.

This Comment discusses the revisions needed in equal protection doctrine to enable courts to evaluate whether preguancy-based laws proniote or detract from gender equality. Part I describes state laws that provide pregnancy, childbirth, or maternity leave for women workers. Part II reviews constitutional precedent regarding employment laws that

14. For the text of the PDA, see supra note 8.

15. For a discussion of the intermediate level of review of gender classifications, see infra notes 55-56 and accompanying text. 
govern pregnant employees, and criticizes the doctrine's imphicit biological deterininism. Part III argnes that constitutional doctrine should focus on the social impact of legal treatment of pregnancy as does title VII. Part IV discusses the Court's rulings in Miller-Wohl and Cal Fed and their imphications for the development of a judicial standard capable of evaluating whether a law's treatment of biological difference constitutes equal treatment. Finally, Part V outlines the proposed revised constitutional standard and apphes it to state laws that provide employment leave for woinen.

\section{I}

\section{State Laws That Provide Pregnancy-Related LEAVE FROM EMPLOYMENT}

Several states have passed laws that require employers to provide a leave of absence to women for pregnancy and childbirth. ${ }^{16}$ The laws vary im such factors as how long a leave is permitted, what reasons for leave are permissible, and whether the leave is conditioned upon actual disability resulting from pregnancy or childbirth. All of these laws, however, make an employment benefit available to women on the basis of their childbearing capacity without requiring comparable benefits for men.

California's statutory provision for pregnancy leave, at issue in California Federal Savings \& Loan Association v. Guerra, ${ }^{17}$ exemplifies a narrowly drawn statute. As part of a statutory scheme prohibiting employment discrimination, the California pregnancy-leave statute requires einployers to allow feinale employees to take an unpaid leave for up to four months for disability resulting from pregnancy, childbirth, or related medical conditions. ${ }^{18}$ The state statute provides, $\mathrm{m}$ effect, qualified job security for women who must leave work temporarily to cope with physical problems resulting from pregnancy or to give birth. ${ }^{19}$ The

16. See, e.g., CAL. Gov'T CoDE $\S 12945(b)$ (2) (West 1980); ConN. GEN. STAT. ANN. § 46a60(a)(7)(B) (West 1986); Iowa CODE ANN. $§ 601$ A.6.2.e (West 1988); MASS. GEN. LAws ANN. ch. 149, § 105D (West Supp. 1988); MoNT. CodE ANN. § 49-2-310(2) (1987); TENN. Code ANN. $\S 4-21-408$ (Supp. 1988) (amending $\$ \S 50-1-501$ to -505 (Supp. 1987)).

17. 107 S. Ct. 683 (1987).

18. CAL. Gov'T CODE $\$ 12945$ (West 1980). Section 12945 provides, in pertinent part: It shall be an unlawful einployment practice unless based upon bona fide occupational qualification:

(b) For any einployer to refuse to allow a feinale einployee affected by pregnancy, childbirth, or related medical conditions ....

(2) To take a leave on account of pregnancy for a reasonable period of time; provided, such period shall not exceed four inonths. . . Reasonable period of time ineans that period during which the feinale employee is disabled on account of pregnancy, childbirth, or related medical conditions.

19. The regulations implementing the statute require employers to reinstate the woman in her previous job or a substantially similar job unless the employer can show that doing so would 
statute entitles a woman to a leave of absence only for as long as she is disabled but not to exceed four months. ${ }^{20}$

An example of a broadly drafted statute was the original version of the Tennessee Maternity Leave Act. ${ }^{21}$ The Act required employers to provide full-time female employees with up to four months leave "for the purpose of bonding with a newly born or newly adopted child."22

The most striking feature of Tennessee's maternity leave was that it was not directly linked to women's reproductive capacity. Presumably, a woman needimg time off from work for childbirth could have taken advantage of the statute, as the leave was available to women who "because of a medical emergency" were unable to give otherwise statutorily required advance notice to the employer. ${ }^{23}$ Nevertheless, the statute did not explicitly mention pregnancy or childbirth. Furtherniore, the statute apphied if the mother adopted the child. No inherent biological difference between women and men makes women more deserving of time to "bond" with a new child; even if one argued that lactation justified providing woinen but not men with leave after the birth of a child, this argument would not justify giving a mother but not a father the option of a leave to bond with an adopted child. Nevertheless, the stat-

"substantially undermine the employer's ability to operate the business safely and efficiently." CAL. ADMIN. CODE tit. 2, § 7291.2(d)(3)(C)(1) (1987).

20. Cal. Gov't Code $\$ 12945(b)(2)$ (West 1980). For text, see supra note 18.

21. TenN. CODE ANN. $\$ \$ 50-1-501$ to -503 (Supp. 1987) (current version at TeNN. Code ANN. § 4-21-408 (Supp. 1988)). Section 50-1-501 provided, in relevant part:

(a) A female employee who has been employed by the same employer for at least twelve (12) consecutive months as a full-time employee ... may be absent from such employment for a period not to exceed four (4) months for the purpose of bonding with a newly born or newly adopted child (. . . hereinafter . . . "maternity leave").

(b) (1) A female employee who gives at least three (3) months advance notice to her employer ... shall be restored to her previous or a similar position with the same status, pay, length of service credit and seniority, wherever applicable, as of the date of her leave.

(2) A female employee who is prevented from giving three (3) months advance notice because of a medical emergency which necessitates that maternity leave begin earlier than originally anticipated shall not forfeit her rights and benefits under this part solely because of her failure to give ... notice.

Section 50-1-502 provided, in relevant part:

(a) Maternity leave may be with or without pay ...

(b) If an employee's job position is so unique that the employer cannot, after reasonable efforts, fill that position temporarily, then the employer shall not be liable under this part for failure to remstate the employec at the end of her maternity leave period.

(c) The purpose of this part is to promote and encourage bondimg between a female employee and her newly born or adopted child. . . .

Section 50-1-503 provided, in relevant part:

Nothing contained within the provisious of this part shall be construed:

(2) To require any employer to provide maternity leave to male employees; or

(3) To apply to any employer who employs fewer than one liundred (100) full-time employees on a permanent basis at the job site or location.

22. Id. $\S 50-1-501(a)$; see also id. $\$ 50-1-502(\mathrm{c})$. The Act applied only to employers with at least 100 full-time employees. Id. $\S 50-1-503(3)$. Further, only women who had worked for thic employer for at least one year were eligible. Id. $\$$ 50-1-501(a).

23. Id. §50-1-501(b). For full text, see supra note 21 . 
ute made explicit that employers were not required "to provide maternity leave to male employees."24

Even before the Tennessee maternity leave provisions were to take effect, the state attorney general issued an opinion suggesting that the provisions might not witlistand scrutimy under the equal protection clause unless the state could justify its interest in "promoting mothercliild 'bonding' as distimct from parent-child 'bondmg." "25 In response, the Tennessee legislature amended tlie statute within a few montlis of it taking effect. ${ }^{26}$ Ratlier tlian extend to men the opportunity to leave work temporarily to "bond" with a child, tle amended version changed the stated purpose of the leave. The leave reinained available only to women but for "pregnancy, childbirtl, and nursing the infant, where applicable."27 Provisions for care for newly adopted children were dropped.

The ainended Tennessee maternity-leave statute resembles the Montana Maternity Leave Act (MMLA) which was cliallenged in MillerWohl Co. v. Commissioner of Labor \& Industry. ${ }^{28}$ The MMLA forbids einployers from firing an employee because of pregnancy and requires einployers to grant an einployee a "reasonable leave of absence" for pregnancy. ${ }^{29}$ The leave of absence is not contingent on actual disability; pregnancy alone entitles an employee to take a "reasonable leave."30 Whether the employee is disabled by her pregnancy is relevant only to whetlier slie qualifies for compensation under an employee's disability plan. ${ }^{31}$ The MMLA also requires an eniployer to reinstate the employee

24. Id. § 50-1-503(2).

25. The Maternity Leave Act, Op. Att'y Gen. No. 87-193 (Dec. 17, 1987).

26. See Tenn. AnN. Code $\S 4-21-408$ (Supp. 1988) (effective Mar. 23, 1988).

27. Id. § 4-21-408(a),(c)(3). Section 4-21-408 provides, in relevant part:

(a) A female einployee ... may be absent froin ... einployinent for a period not to exceed four (4) inonths for pregnancy, childbirth, and nursing the infant, where applicable

(c)(3) The purpose of this section is to provide leave time to feinale enployees for pregnancy, childbirth, and nursing the infant, where applicable;

Like the previous version of the statute, see supra note 22 , the leave is available only to women who have worked for more than a year for an einployer who has at least 100 employees. Id. § 4-21408(a), (d)(3).

28. 107 S. Ct. 919 (1987), vacating 214 Mont. 238, 692 P.2d 1243 (1984).

29. MONT. CODE ANN. § 49-2-310 (1987). Section 49-2-310 provides:

It shall be unlawful for an enployer or his agent to:

(1) terminate a woman's employment because of her pregnancy;

(2) refuse to grant to the employee a reasonable leave of absence for such pregnancy;

(3) deny to the einployee who is disabled as a result of pregnancy any coinpensation to which she is entitled as a result of the aceumulation of disability or leave benefits accrued pursuant to plans inaintained by her einployer, provided that the einployer inay require disability as a result of pregnancy to be verified by medical certification that the employee is not able to perform lier employment duties; or

(4) require that an einployec take a mandatory inaternity leave for an unreasonable length of time.

30. Id. $\S 49-2-310(2)$.

31. Id. $\S 49-2-310(3)$. 
in her original job or an equivalent one, although private einployers inay be relieved of this requirement if changed circumstances make reinstatement "impossible or unreasonable." 32

Like California, Connecticut inakes explicit that female employees are entitled to a leave of absence only for "disability resulting from ... pregnancy."33 Connecticut also distimguishes between leave for women triggered by pregnancy disability and "family leave" for both men and women triggered by the birth or adoption of a child. Leaving the pregnancy-leave statute undisturbed, the Connecticut legislature in 1987 enacted a "family leave" policy allowing male and female permanent state employees to take a leave of up to twenty-four weeks within any two-year period because of the birth or adoption of a child, serious illness of a child, spouse, or parent of the einployee, or serious illness of the employee himself or herself. ${ }^{34}$ The act inakes explicit that state employees are entitled to family leave "in addition to" leave for pregnancy disability. ${ }^{35}$ Other states require employers to provide gender-neutral parental leave, somewhat similar to Connecticut's family leave, but do not require employers to provide leave for pregnancy disability. ${ }^{36}$

32. Id. $\$ 49-2-311$. The section provides:

Upon signifying her intent to return at the end of her leave of absence, such employee shall be reinstated to her original job or to an equivalent position with equivalent pay and aceumulated seniority, retirement, fringe benefits, and other service credits unless, in the case of a private employer, the employer's circumstances have so changed as to make it impossible or unreasonable to do so.

33. ConN. Gen. Stat. ANN. $\S 46 a-60(a)(7)(B)$ (West 1986). Part of the statutory scheme prohibiting discriminatory einployinent practices, the section provides in relevant part:

It shall be a discriminatory practice in violation of this section: . . .

(7) For an employer... (A) To terminate a woman's employment because of her pregnancy; (B) to refuse to grant to that employee a reasonable leave of absence for disability resulting from her pregnancy; (C) to deny to that einployee, who is disabled as a result of pregnancy, any compensation to which she is entitled as a result of the accunnulation of disability or leave benefits accrued pursuant to plans maintained by the einployer; (D) to fail or refuse to reinstate the einployee to her original job or to an equivalent position with equivalent pay and . . . other service credits upon her signifying her intent to return unless, in the case of a private employer, the employer's circumstances have so changed as to inake it impossible or unreasonable to do so ....

34. Act approved May 20, 1987, Public Act No. 87-291, 1987 Conn. Acts 427, reprinted in

ConN. Gen. StAT. ANN. app. at 76 (West 1988). The Act provides in pertinent part:

Section 1. (a) Each permanent employee ... shall be entitled to the following: (1) A maximum of twenty-four wceks of family leave of absence within any two-year period upon the birth or adoption of a child of such employee, or upon the serious illness of a child, spouse or parent of such employee; and (2) a maximum of twenty-four weeks of medical leave of absence within any two year period upon the serious illness of such employee.... .

(b) The leave of absence benefits granted by this section shall be in addition to any other paid leave benefits and benefits provided under subdivision (7) of subsection (a) of section $46 a-60$ of the general statutes ....

35. Id. $\S 1(\mathrm{~b})$.

36. See, e.g., MinN. STAT. ANN. $\$ \S 181.940$ - 181.943 (West Supp. 1988) (providing employees up to six weeks leave for birth or adoption of a child); R.I. GEN. LAws $\S 28-48-1$ to -9 (Supp. 1987) (providing employees up to thirtecn consecutive work weeks of parental leave in any two calendar years, including leave for birth of a child). The need for parental leave is analytically distinct from the need for leave for pregnancy or childbirth. While both women and men have a claim to lcave for 
The California; Tennessee, Montana, and Connecticut pregnancyleave provisions, in contrast to the family or parental leave statutes, permit employers to treat women and men differently. The question which employers have raised in the courts-and femmist legal activists and scholars have debated-is whether this different treatinent is prohibited by the equal protection clause of the fourteenth amendment and by title VII. The constitutional precedent that bears on this debate is discussed in the following Part.

II

\section{The Current Constitutional ApProach to Pregnancy and GENDER Equality}

The fourteenth amendment provides that no state shall deny "to any person within its jurisdiction the equal protection of the laws."37 Does a law that simgles out pregnancy as a condition for einployınent benefits violate this constitutional gnarantee by treating women and men differently? The Supreme Court's imterpretation to date of the equal protection clause provides hittle help in answernig this question; the Court has held that laws governing pregnancy do not raise a question of equal protection of women and men. Although the Court has recognized that laws governing pregnancy may infringe on a woman's due process right to bear a child, the Court's equal protection reasoning accepts biological difference as sufficient justification for different treatment of women and men.

\section{A. The Due Process Right to be Free From Arbitrary Pregnancy-Based Barriers}

In the early 1970s, in Cleveland Board of Education v. LaFleur, ${ }^{38}$ the Supreme Court used a due process analysis to invalidate an employer pohicy concerning pregnant women. LaFleur was a consolidation of constitutional challenges by female scliool teacliers to school board policies that imposed mandatory maternity leaves on pregnant teachers at an early point in tlieir pregnancies. The Court lield that arbitrary employment cutoff and return dates for pregnant woinen, with no individualized inquiry into a woman's ability to work and potentially bittle relation to the majority of childbearing women's ability to work, impermissibly infringed on women's constitutionally guaranteed due process right to

caring for cliildren, women lave an additional claim to leave for disability resulting from pregnancy and childbirth. As Connecticut las recognized, parental leave and pregnancy leave complement ratlier than supplant eacli otlier.

37. U. S. CONST. amend. XIV, §1.

38. 414 U.S. 632 (1974). 
choose to bear a child. ${ }^{39}$

Although the courts below had based their decisions on equal protection, the Supreme Court adopted a due process analysis. ${ }^{40}$ This doctrinal choice reflected the Court's unwillingness to conceptualize pregnancy as having any impact on gender equality. Nevertheless, LaFleur contributed to gender equality by rejecting the assuinption imphicit in mandatory maternity leave that pregnant women cannot, or at least ought not, work outside the home.

First, the Court rejected the school boards' justification that a woman in her fourth or fifth month of pregnancy is physically incapable of hanilling her job responsibilities. In the Court's words, such a presumption "sweep[s] too broadly." 41 Rather than accept the ideological notion that pregnant women are unable to work, the Court reasoned that physical competence to work is a factual question. It found that individualized determinations, or perhaps shorter, factually justifiable inandatory leaves, are the only constitutionally permissible means of distimgnishing between pregnant women who are and are not capable of performing their jobs. ${ }^{42}$

The Court also implicitly criticized the ideology that pregnancy is an aberration in the public sphere of paid employment. As the Court noted, the pohcies may have been motivated by "outmoded taboos," reflected in testimony by school officials that they wanted to "save" women who "show" from "embarrassment at the hands of giggling schoolchildren" and to protect students from the sight of "conspicuously pregnant women." 43 The officials' statements show how provisional women's acceptance in the workforce was and, to some degree, still is. Women are acceptable as teachers only so long as they conform to the inodel of the male teacher whose private sexual hfe need never be physi-

39. Id. at $647-48$.

40. See La Fleur v. Cleveland Bd. of Educ., 326 F. Supp. 1208 (N.D. Ohio 1971), rev'd, 465 F.2d 1184 (6th Cir. 1972); Cohen v. Chesterfield County School Bd., 326 F.Supp. 1159 (E.D. Va. 1971), rev'd, 474 F.2d 395 (4th Cir. 1973). In the Supreme Court decision, Justice Powell concurred in the judgment on the grounds that the policies violated equal protection; however, refusing to take a position as to whether a sex-based classification was at issue, he held that the policies did not withstand a rational-basis standard of review. LaFleur, 414 U.S. at 651, 653 \& n.2 (Powell, J., concurring).

41. LaFleur, 414 U.S. at 644.

42. Id. at 645-48. To the extent that LaFleur endorsed a general constitutional prohibition against laws that relied on "conclusive presumptions" rather than individualized determinations, the Supreme Court has subsequently rejected this reading of LaFleur. See Matlews v. Lucas, 427 U.S. 495 (1976) (upholding irrebuttable presumption deeming only certain classes of illegitinate children dependent for purposes of determining their eligibility for survivor benefits under Social Security Act); Weinberger v. Salfi, 422 U.S. 749, 772 (1975) (permitting conclusive presumption excluding wives who fail to meet duration-of-relationship requirement from receiving widow's benefits under Social Security Act).

43. LaFleur, 414 U.S. at 641 n.9. 
cally in evidence. By invalidating public policies that rely imphicitly on this ideology, LaFleur contributed significantly to the acceptance of pregnancy in the pubhic sphere.

Following LaFleur's due process analysis, the Supreine Court struck down anotlier state statute that presumed pregnant women's inability to work. In a short per curiam opimion in Turner v. Department of Employment Security, ${ }^{44}$ the Court held unconstitutional a Utah law that made pregnant women ineligible for unemployment compensation for the twelve weeks preceding and six weeks following the expected date of childbirth. The statute conclusively presumed that pregnant women were unable and unavailable to work during this period and thus were inehgible for unemployment benefits. Relymg on LaFleur, the Court reasoned that due process required a inore individualized determination of pregnant women's ability to work since, as was true of the particular plaintiff in the case, "a substantial number of women are fully capable of working well into their last trimester of pregnancy and of resuming einployment shortly after childbirth."45

\section{B. The Irrelevance of Pregnancy to Equal Protection of Women and Men}

Although the Court in LaFleur and Turner held that due process entitled women to reproductive choice, only six inonths after LaFleur the Court refused to acknowledge that society's pohicies towards women's reproductive capacity affect women's relative status in the work world and thus raise an issue of equal protection of women and inen. In Geduldig v. Aiello, ${ }^{46}$ the Court upheld against an equal protection challenge a California disability system that failed to provide compensation for disability resulting from normal pregnancy. The Court concluded that, absent a showing of intent to discriminate agamst women, laws that classify on the basis of pregnancy do not constitute gender-based classifications. ${ }^{47}$

In Geduldig, four women who had been disabled froin work because of pregnancy argued that the state-run disability system impenmissibly discriminated on the basis of sex because it provided benefits to employees for almost all disabilities except normal pregnancy. Finding no violation of the equal protection clause, the Geduldig majority refused to categorize the law's pregnancy-based classification as a gender-based classification. Rather, in a now infainous footnote, the Court described the classification as one between "pregnant women and nonpregnant per-

44. 423 U.S. 44 (1975) (per curiam).

45. Id. at 46.

46. 417 U.S. 484 (1974).

47. Id. at $496-97 \&$ n.20. 
sons," with the latter including both woinen and inen. ${ }^{48}$

The Court isolated employer treatment of pregnancy from employer treatment of women by characterizing pregnancy as "an objectively identifiable physical condition with umique characteristics," with no more significance for gender identity than any other umique physical condition. ${ }^{49}$ Accordimgly, absent a showing that lawmakers had used pregnancy as a pretext for sex discrimination, pohicies toward pregnant workers were not relevant in assessing whether female and male einployees received equal treatment. ${ }^{50}$

The Geduldig Court's view of equality implicitly takes the male worker as the yardstick for ineasuring equality; only those characteristics that women and inen share are relevant for ineasuring equality. Thus, the Court found that the disability systein did not raise the issue of equality between the sexes because "[ $t]$ here is no risk from which men are protected and woinen are not. Likewise, there is no risk from which women are protected and men are not."5i

By separating pregnancy froin gender, the Court also ensured deferential judicial review of laws governing pregnancy. The Court explicitly stated, "lawmakers are constitutionally free to include or exclude pregnancy from the coverage of legislation ... on any reasonable basis, just as with respect to any other physical condition." 52 Under the deferential "rational basis" standard of review, a law inay be successfully challenged only if it is patently irrational. ${ }^{53}$ In most cases, any rational reason will suffice, whether or not it was the reason that inotivated passage of the law. ${ }^{54}$ Thus, unless the Court overrules Geduldig or plaintiffs distinguish their particular cases, courts are very unlikely to invalidate pregnancybased laws on equal protection grounds.

By contrast, had the Court treated pregnancy-based laws as classifying by gender, such laws would have been subject to a higher degree of scrutiny. A statute tliat classifies by gender is entitled to an "intermediate" level of judicial review. ${ }^{55}$ Under this level of scrutiny, "classifica-

\footnotetext{
48. Id. at $496 \mathrm{n} .20$.

49. Id.

50. Id.

51. Id. at 496-97.

52. Id. at 496 n.20.
}

53. Under a "rational basis" standard, a court will uphold a challenged law if it is rationally related to a legitimate government interest. New Orleans v. Dukes, 427 U.S. 297, 303 (1976).

54. See, e.g., id. (upholding city's restriction on pushcart vendors as rational means of achieving city's objective). But of. City of Cleburne v. Cleburne Living Center, Inc., 473 U.S. 432 (1985) (zoning ordinance invalid because irrational where applied to deny permit for residential home for the mentally retarded).

55. G. GuNTHER, Constitutional LAw 591 (11th ed. 1985); see also Harris v. McRae, 448 U.S. 297, 342 n.3 (1980) (Marshall, J., dissenting) (observing that the Court has adopted an "intermediate" level of scrutiny for gender classifications). 
tions by gender must serve important governmental objectives and must be substantially related to achievement of those objectives" to withstand an equal protection challenge. ${ }^{56} \mathrm{Had}$ Geduldig categorized pregnancybased laws as gender-based classifications, constitutional challenges to these laws would have more chance of success. ${ }^{57}$

Nevertheless, without a change in the Court's analysis of the relationship between biological difference and gender equality, merely categorizing pregnancy-based laws as gender-based classifications would not necessarily trigger the searching scrutiny such laws deserve. When scrutinizing laws that explicitly differentiate on their face by gender but that mvolve women's reproductive capacity, at least a plurality of the Court has inade some of the same troubling assumptions about biological difference that the Court used in Geduldig. In Michael M. v. Superior Court, ${ }^{58}$ the Court rebuffed an equal protection challenge to a California statute that makes sexual intercourse with minors a crime for men but not for woinen. Because the statute classified on its face by gender, the Court ostensibly applied intermediate scrutiny. ${ }^{59}$ After examining whether the gender classification served the state's purported objective of preventing illegitimate teenage pregnancies, the plurality concluded that a woinan's capacity to become pregnant justified the gender classification. ${ }^{60}$ In Justice Relnquist's words:

We need not be medical doctors to discern that young men and young women are not similarly situated with respect to the problems and the

56. Craig v. Boren, 429 U.S. 190, 197 (1976). For a more demanding version of intermediate scrutiny, see Mississippi Univ. for Women v. Hogan, 458 U.S. 718 (1982), discussed infra at notes 174-186 and accoinpanying text.

57. The decision not to characterize pregnancy-based classifications as gender-based classifications inay have been the result of a dispute on the Court at the tine of Geduldig over what degree of scrutiny to afford gender-based classifications. By the time Geduldig was decided, a majority of the Court had agreed that a gender-based classification would withstand an equal protection challenge only if the classification had "a fair and substantial relation to the object of the legislation," a stronger standard than minimal rationality. Reed v. Reed, 404 U.S. 71, 76 (1971). The year before Geduldig, four Justices concluded that gender classifications are "suspect" and therefore entitled to "strict scrutiny." Frontiero v. Richardson, 411 U.S. 677, 688 (1973). A law will survive strict scrutiny only if the classification is necessary to promote a compelling government interest, a test that almost no law has survived. The only case in which the Supreine Court has upheld a racial classification under strict scrutiny is the much criticized Koreinatsu v. United States, 323 U.S. 214 (1944). Korematsu is also the first case in which the Court characterized race as a "suspect" criterion. Id. at 216; G. GUNTHER, ConstrTutional LAW 624 (11th ed. 1985). In Geduldig, the inajority may have refused to categorize pregnancy-based laws as gender-based classifications either to avoid a decision on whether gender classifications were "suspect" or to restrict the scope of the category as a hedge against the possibility that a majority would hold gender classifications "suspect" at some future time. Indeed, the dissent in Geduldig argued not only that a pregnancy classification was a sex-based classification but also that the Court should subject it to strict scrutiny. 417 U.S. at 503 (Brennan, J., dissenting).

58. 450 U.S. 464 (1981).

59. Id. at $468-69$.

60. Id. at $470-74$. 
risks of sexual intercourse. Only women may become pregnant and they suffer disproportionately the profound physical, emotional, and psychological consequences of sexual activity. ${ }^{61}$

Although Rehnquist claims to be applying the heightened standard of review for gender classifications, his reasoning is ambiguous. He implies that a statute whose justification is "the problems and risks of sexual mtercourse" either easily satisfies the standard of review or does not even raise an issue of equal protection because biological difference vitiates women's and men's claim to similar treatment. Under either reading, Michael $M$. raises doubt as to the force of imtermediate scrutiny when applied to a gender classification whose proferred justification is biological difference.

\section{The Court's Biological Determinism}

The Court's analysis of biological difference, whether in regard to laws governing pregnancy or gender-based laws justified by women's childbearing capacity, is dangerous because it freezes in place the social arrangements surrounding pregnancy and childbirth. In effect, the Court's current equal protection analysis exeinpts such arrangements from serious judicial scrutiny. It mistakenly identifies society's treatment of pregnancy as the immutable resnlt of biology itself. Biological determinism becoines the justification for socially created inequality.

Geduldig reflects this biological determinism; rather than examine how employer treatment of pregnancy affects women's status in the work force, it accepts such treatment as necessitated by the biological fact of pregnancy. This approach marginalizes pregnancy, defining it as women's private concern, of no relevance to equalizing woinen's and men's position in the work force. The Court's analysis also leaves intact existing social arrangements which encourage women to assuine primary caretaking responsibilities, regardless of whether these arrangements reinforce damaging stereotypes that perpetuate women's subordinate status. As long as employment pohicies are structured with the male worker as model, the Court's constitutional analysis reinforces women's secondary status in the work world. Existing equal protection doctrine neither requires that employment policy remove barriers to women's access nor challenges the ideology that biology justifies these barriers.

Even when scrutinizing a law that classifies on its face by gender, the Court mistakenly focuses on biological difference rather than on the cultural and social meanings society has attributed to biological difference. Michael $M$. illustrates the point. For Rehnquist, the case is straightforward. Woinen get pregnant; men do not. From this fact of

61. Id. at 471 . 
"nature", Rehnquist concludes that the state has good reason to punish men who have sex with young women but not to punish women who have sex with young men. ${ }^{62}$ The basic flaw in this reasoning is that the statute does uot reflect "nature" but, instead, reflects the social construction of biological difference.

As Justice Brennan points out in dissent in Michael M., the historical record shows that the law was not enacted to prevent teenage pregnancy but to protect young women "deemed legally incapable of consenting to an act of sexual intercourse. ... In contrast, young men were assunied to be capable of making such decisions for themselves." 63 This perception of male/female difference may well accurately reflect the socially created power imbalance between women and men. What is noteworthy is that the historical justification for the law, protectimg women from male dominance, is not biological but social. The "profound physical, emotional, and psychological consequences" of which Rehnquist speaks ${ }^{64}$ are largely the products of social arrangements regarding pregnancy. Thus, contrary to Rehnquist's reasoning, the biological fact that women get pregnant neither explains nor justifies the statute in Michael M. . The Court's biological determinism, however, hindered it from examining the inplicit assuniptions and impact of the statute.

Rather than foreclose serious judicial review of pregnancy-based classifications and gender-based classifications that involve women's childbearing capacity, constitutional doctrine should provide for scrutiny of such laws based on an analysis of the impact of legal treatment of biological difference on gender equality. The following Part describes the reform of title VII, the federal statute which prohibits sex discrimination in employment, and concludes that constitutional analysis should follow a similar direction as well.

III

Pregnancy Discrimination as Sex Discrimination UNDER TITLE VII

Although the Court has not repudiated its equal protection analysis

62. Rehnquist writes,

Because virtually all of the significant harmful and inescapably identifiable consequences of teenage pregnancy fall on the young female, a legislature acts well within its authority when it elects to punish only the participant who, by nature, suffers few of the consequences of his conduct. It is hardly unreasonable for a legislature acting to protect minor fenules to exclude then froin punishment. Moreover, the risk of pregnancy itself constitutes a substantial deterrence to young females. No similar natural sanction deter inales.

Id. at 464 (eniphasis added).

63. Id. at 494-96 (Breunan, J., dissenting).

64. See supra text acconipanying note 61 . 
under Geduldig, feminist activists and ultimately Congress have forced the Court to change its approach when enforcing title VII of the Civil Rights Act of 1964. Title VII prohibits einployers from firing, hiring, or making other einployinent decisions on the basis of an "individual's race, color, rehigion, sex, or national origin."65 In 1978, in response to the Court's decision in General Electric Co. v. Gilbert, ${ }^{66}$ Congress passed the Pregnancy Discrimination Act (PDA), amending title VII to clarify that discrimination based on pregnancy, childbirth, or related medical conditions constitutes sex discrimination within the meaning of the statute. ${ }^{67}$

\section{A. Repudiation of the Geduldig Reasoning}

The motivation behind introduction of the PDA was the Court's decision im General Electric Co. v. Gilbert. ${ }^{68}$ In Gilbert, a class of woinen einployees brought a title VII challenge against an einployer's policy which, like the California systein at issue in Geduldig, denied benefits to employees suffering disability from pregnancy but provided such benefits to einployees teinporarily disabled by other nonoccupational causes. Gilbert was different, however, in that the action rehed on the meaning of title VII's prohibition against sex discrimination in employinent, not the meaning of the equal protection clause of the fourteenth anendinent. Using the same reasoming as in Geduldig, the Court concluded that an employer's pohicy regarding pregnancy benefits did not raise an issue of sex discrimination. ${ }^{69}$ Exclusion of pregnancy benefits was not genderbased discrimination because "pregnancy-related disabilities constitutc an additional risk, umque to woinen."70 Thus, whether the mandate for equality was statutory or constitutional, the Court innosed the saine interpretation: Einployer treatinent of pregnancy does not factor into the equation of equahty between woinen and men because pregnancy is umique to woinen. ${ }^{71}$

65. 42 U.S.C. $\$ 2000 \mathrm{e}-2$ (a) (1982). For full text, see supra note 7.

66. 429 U.S. 125 (1976).

67. 42 U.S.C. $\$ 2000 \mathrm{e}(\mathrm{k})(1982)$. For full text, see supra note 8.

68. 429 U.S. 125 (1976). In Newport News Shipbldg. \& Dry Dock Co. v. Equal Employment Opportunity Comm'n, 462 U.S. 669, 676-79 (1983), the Supreme Court acknowledged that Congress, by passing the PDA, repudiated the Court's reasoning in Gilbert.

69. Gilbert, 429 U.S. at 140.

70. Id. at 139 (emphasis in original).

71. For the Court's similar analysis of the constitutional question, see supra notes $46-51$ and accompanying text.

Gilbert also rejected the claim that the policy had a disproportionate impact on women. Id. at 138. In the Court's view, women were not necessarily receiving fewer overall benefits than were men. Id. Mere denial of pregnancy-related benefits did not suffice as proof of disproportionate impact. Id. In a case following Gilbert but preceding passage of the PDA, the Court found that an employment policy that deprived women of aceumulated seniority when they took pregnancy leave did have a disproportionate impact. Nashville Gas Co. v. Satty, 434 U.S. 136 (1977). The Court concluded that the deprivation of seniority "imposed on women a substantial burden that men need 
Feminists-along with labor unions, civil rights groups, and others-formed the Campaign to End Discrimination Against Pregnant Workers in reaction to the Gilbert decision. ${ }^{72}$ This coalition advocated passage of the PDA on the grounds that biological difference does not and should not justify disadvantageous treatinent of wonien. Attacking the assuniptions underlying the Court's refusal to recognize that pohicies towards pregnancy affect the relative status of women and nien, the coahition argued instead that prevailing attitudes about pregnancy had created and perpetuated women's second-class status in the work force.

Testifying in Congress in favor of the PDA, cainpaign cochair Susan Deller Ross stated that "employers use wonren's role as childbearer as the central justification of and support for discrimination against women workers. Thus, discrimination against wonen workers cannot be eradicated unless the root discrimination, based on pregnancy and childbirth, is also eliminated."73 The congressional testimony of Wendy Williains, the lawyer who had represented the employees in Geduldig, cataloged the history of bias against wonen that derived fronı wonien's biological capacity to bear children. She concluded that "the cominon thread of justification running through inost policies and practices that discriminated against wonien in the labor force rested ultinnately on the capacity and fact of pregnancy and the roles, behavior patterns and mythologies surrounding it."74

As several cominentators ${ }^{75}$ and the Supreme Court ${ }^{76}$ itseif have noted, Congress repudiated the fundainental premise of Gilbert and, by implication, the logic of Geduldig when it passed the PDA. Whereas the Supreme Court's analysis in Geduldig and Gilbert had foundered on the issue of biological difference, Congress recognized that the central issue was social mequality premised on biological difference, rather than biological difference itself. Justifying the need for the PDA, the Senate Report acknowledged that biological difference had been used unnecessarily to disadvantage wonien:

not suffer." 'Id. at 142. Nashville Gas, however, did not overrule Gilbert. The Court upheld the portion of the employer's policy that refused to provide sick-leave pay for pregnancy-related absences. Id. at 143-46. As men could not use such a benefit, failing to provide such a benefit to women did not constitute discrimination.

72. J. Gelb \& M. Palley, Women and Public Policies 159-60 (1982).

73. Hearing on H.R. SOSS and H.R. 6075 Before the Subcomm. on Employment Opportunities of the House Comm. on Educ. and Labor, 95th Cong., 1st Sess. 31-32 (1977) (prepared statement of Susan Deller Ross, on behalf of the Campaign to End Discrimination Against Pregnant Workers).

74. Id. at 11 (prepared statement of Wendy Williams, professor of law, Georgetown Law School).

75. See, e.g., Kay, Equality and Difference, 1 BERKLEY WOMEN's L.J. 1, 8 (1985); Wiliams, Equality's Riddle: Pregnancy and the Equal Treatment/Special Treatment Debate, 13 N.Y.U. REV. L. \& Soc. ChaNGE 325, 348 (1984-85).

76. Newport News Shipbldg. \& Dry Dock Co. v. Equal Employment Opportunity Comm'n, 462 U.S. 669,684 (1983). 
[T]he assumption that women will become pregnant and leave the labor market is at the core of the sex stereotyping resulting in unfavorable disparate treatment of women in the workplace. A failure to address discrimmation based on pregnancy, in fringe benefits or in any other employment practice, would prevent the elimmation of sex discrimination im employment. ${ }^{77}$

By incorporating pregnancy-related conditions into the definition of sex discrimination, the PDA recognized the significance of pregnancybased distinctions for gender equality.

\section{B. Implications of the PDA for Constitutional Analysis}

The PDA exposes the flaws in the Court's reasoning in Geduldig and Gilbert. First, as the PDA recognizes, the way a society deals with woinen's reproductive capacity affects the relative status of women and men in the society. Laws that distingnish on the basis of pregnancy are sex-based laws. Since passage of the PDA, the Court, in deference to Congress, has accepted that pregnancy discrimination constitutes sex discrimination under title VII. ${ }^{78}$

Second, the PDA imphies that the economic, social, or political situation of the sexes is not biologically inevitable; society can alter these social relationships by changing social attitudes and practices, including changing the law. As proponents of the PDA had argued, woinen's reproductive capacity has historically served as a principal justification for women's subordinate social, economic, and political status. ${ }^{79}$ Passage of the PDA helped sever this link between woinen's childbearing capac-

77. S. REP. No. 331, 95th Cong., 1st Sess. 3 (1977).

78. Newport News Shipbldg. \& Dry Dock Co. v. Equal Employment Opportunity Comm'n, 462 U.S. 669, 684 (1983) (clarifying that "for all Title VII purposes, discrimination based on a wornan's pregnancy is, on its face, discrimination because of her sex.").

79. See supra notes 73-74 and accompanying text. An example of how women's reproductive capacity was used to justify their secondary status in the workforce is the Court's reasoning in Muller v. Oregon, 208 U.S. 412 (1908). Upholding restrictions on working hours for women, the Court reasoned that woinen needed protection because their reproductive capacity affected their "capacity for long-continued labor" and made them inherently dependent on men. Id. at 421-22.

Feminist historians have documented that women's reproductive capacity was used as a justification for curbing their econounic opportunities, thereby reducing the economic threat women posed to male workers. See Hartman, Capitalism, Patriarchy, and Job Segregation, in CapiTal15T PATRIARChY AND THE CASE FOR SOCIALIST FEMINISM 206, 218, 227-28 (Z. Eisenstein ed. 1979); Kessler-Harris, "Where are the Organized Women Workers?", in A Heritage of Her Own 343, 353-55 (1979). Because woinen were largely unskilled and not unionized, they represented an attractive source of labor for employers and posed a threat to unionized men's jobs. While these factors contributed to exploitative working conditions for woinen and led social reformers to fight for protective legislation, these factors also led unions to inake protective legislation for women a higher priority than organizing women workers. The unions' justification was women's role as wife and mother. As one union meinber wrote in 1900 , "it is to the interest of all of us that female labor should be limited so as not to injure the motherhood and family life of a nation." Kessler-Harris, supra, at 354. 
ity and their subordination in the workforce. By prohibiting pregnancy discrimination, it helped change the social consequences of pregnancy. Under title VII as amended by the PDA, the woinan whoin an employer may have fired merely because of pregnancy is now legally entitled to keep her job if she can do the work.

Passage of the PDA, however, did not alter constitutional doctrine. The Court is under no compulsion to defer to Congress when interpreting the equal protection clause, and it has not overruled Geduldig. Equal protection doctrine accepts social reality as the inevitable result of biological difference and hence perpetuates existing social relationships, whether oppressive to women or not.

Further, the PDA did not provide an affirmative definition of gender equahty. Congress clearly prohibited eniployers from penalizing employees because of pregnancy, but it left unresolved whether einployers could provide preferential treatment because of pregnancy. The legislative history provided no clear-cut answer as to whether the prohibition against pregnancy discrimination required identical treatment of men and women without regard to biological difference or permitted recognition of biological difference as long as that recognition did not harm wonien.

The legal challenges to state laws that provide employment leave for pregnancy gave the Supreme Court the opportunity to bring its equal protection doctrine into line with the doctrinal development in title VII and to clarify the meaning of the constitutional and title VII mandates of gender equality. As Part IV describes, the Supreme Court did not fully respond to this challenge.

\section{IV}

\section{CaL Fed and Miller-Wohl: The Debate About EQUALITY}

By the time the Court faced challenges to the Montana and California pregnancy-leave statutes, pregnancy jurisprudence contained conflicting analytic frameworks for evaluating whether laws that distingnish on the basis of pregnancy promote or detract from equality between the sexes. Equal protection doctrine defined laws governing einployer treatment of pregnancy as irrelevant to gender equality; virtually any pohicy withstood equal protection scrutimy. By contrast, title VII prohibited practices that discriminate on the basis of pregnancy because such practices constitute sex discrimination. Neither the constitutional nor statutory doctrine provided an analytic framework for differentiating between permissible and impermissible pregnancy-based distinctions. In short, the jurisprudence of pregnancy discrimination was in chaos. ${ }^{80}$

80. In a 1988 speech, Justice O'Connor characterized the doctrine to date as consisting of the 
The lawsuits challenging state pregnancy-leave statutes, MillerWohl Co. v. Commissioner of Labor \& Industry ${ }^{81}$ and California Federal Savings \& Loan Association v. Guerra, ${ }^{82}$ brought the conceptual and doctrinal confusion out into the open. These cases generated debate in the feminist community about what model of equality should inform the legal doctrine. Despite the need to sort out the conflicting models of equality in the doctrme and develop a coherent analysis, the Court's resolution of the two cases provided only a first step in this direction.

\section{A. Miller-Wohl}

The first of these cases to reach the Court was Miller-Wohl, which challenged the validity of the Montana Maternity Leave Act (MMLA). ${ }^{83}$ The case began when a Montana clothing store, owned by the MillerWohl corporation, fired Tamara Buley after she repeatedly experienced pregnancy-related nausea and vomiting during the first few weeks on the job. ${ }^{84}$ Buley filed a complaint with the Montana Commissioner of Labor and Industry who found that the employer had violated the Montana law by firing Buley. ${ }^{85}$ Seeking judicial review of the Commissioner's findings, the employer did not dispute that it had violated the Montana law, ${ }^{86}$ but instead sought an injunction against enforcement of the state law and a declaration that the state law was invalid. ${ }^{87}$

The employer challenged the state law on both constitutional and statutory grounds. The central constitutional clain was that the Montana law violated the federal equal protection clause. ${ }^{88}$ The employer

Court's "awkward attempts to come to grips with the problem of how physical differences between the sexes should affect their treatment under the law." Smothers, Conferees Seek "Founding Mothers", N.Y. Times, Feb. 12, 1988, at B6, col. 4.

81. 107 S. Ct. 919 (1987), vacating 214 Mont. 238, 692 P.2d 1243 (1984).

82. 107 S. Ct. 683 (1987).

83. MoNT. Code ANN. $\S \S 49-2-310$ to -311 (1985). For full text and discussion of the state law, see supra notes $29-32$ and accompanying text.

84. Miller-Wohl, 214 Mont. at 242, 692 P.2d at 1245.

85. Miller-Wohl Co. v. Comm'r of Labor \& Indus., 515 F. Supp. 1264, 1265-66 (D. Mont. 1981), vacated for lack of subject matter jurisdiction, 685 F.2d 1088 (9th Cir. 1982).

86. 515 F. Supp. at 1266.

87. The employer intially filed in a United States district court, which upheld the validity of the state law. Id. at 1264. On appeal, the Ninth Circuit vacated the judgment and dismissed for lack of subject matter jurisdiction because Miller-Wohl had raised federal defenses against a state law claim but had not pleaded a federal claim. 685 F.2d 1088, 1090 (9th Cir. 1982). Miller-Wohl continued its case in state court. The state district court agreed with the employer and revcrsed the Commissioner's order. 214 Mont. at 243, 692 P.2d at 1246. The Montana Supreme Court reversed. Id. at $262,692 \mathrm{P} .2 \mathrm{~d}$ at 1255 .

88. 214 Mont. at 249,692 P.2d at 1248-49. The summary of the arguments that follows in the text is based on the summary by the state supreme court in its opinion. See id.

In the federal district court case, the employer also claimed that forcing the store to adopt a leave policy would constitute a taking of property without due process in violation of the fourteenth amendment. $515 \mathrm{~F}$. Supp. at 1267-68. The district court rejected the due process claim, $i d$. at 1268 , and no subsequent opinion mentions this claim. 
argued that Montana's provision of a leave for preguancy constituted a sex-based classification and thus deserved heightened scrutiny. The law, the einployer asserted, would not pass inuster under intermediate scrutiny or under an affirmative action test because the state law had "no close or substantial relationship to any governmental interest."89 Defending the law, the Commissioner argued that preguancy classifications are not gender-based classifications for the purpose of equal protection analysis, and thus they need only be justified on a reasonable basis. Even if such classifications were considered gender-based, the Commissioner concluded that the law passed inuster under the heightened scrutiny because it bore "a substantial relationship to an inportant state interest." 90 The einployee, appellant Buley, as well as the Woinen's Law Section of the State Bar of Montana appearing as amicus curiae, made smillar arguments. ${ }^{91}$

The einployer also claimed that title VII, as amended by the PDA, conflicted with and thus preeinpted the Montana law. ${ }^{92}$ Miller-Wohl's coinpany pohicy allowed einployees with at least one year seniority to take disability leave, but the MMLA required Miller-Wohl to let pregnant eniployees take a leave even if they were not disabled. Thus, the eniployer argued, the MMLA required it to give preguant employees a benefit to which the other eniployees were not entitled, in essence requiring it to discriminate on the basis of preguancy in violation of title VII. To bolster its interpretation of title VII, the eniployer pointed to the second clause of the PDA which states that "woinen affected by pregnancy, childbirth, or related inedical conditions should be treated the same for all einployment-related purposes . . . as other persons not so affected but similar in their ability or inability to work."93

Rejecting the einployer's arguinent, the Montana Suprenie Court held that title VII did not preenpt the state law. The court reasoned that the state law sought to accoinplish the same objective as the federal actnamely, "equality."94 The MMLA acconiphished this objective by "protect[ing] equal job opportunities for wonien as coinpared to others by removing a fernale disability job risk not faced by inen and nonpreguant feinales." 95

89. 214 Mont. at 249,692 P.2d at 1249.

90. Id. at 248,692 P.2d at 1248.

91. See id. at 249,692 P.2d at $1248-49$.

92. Id.

93. Id. at 254, 692 P.2d at 1251 (quoting 42 U.S.C. $\$ 2000 \mathrm{e}(\mathrm{k})$ (1982)). For the relevant text of the PDA, see supra note 8.

94. 214 Mont. at 241,692 P.2d at 1245.

95. Id. at 241,692 P.2d at 1244-45. The court did not evaluate the law as applied to nondisabled pregnant employees, as the original complainant in the case, Buley, had been disabled by pregnancy. Id. at 259,692 P.2d at $1253-54$. 
The court pushed its title VII analysis one step further. Applying the theory that a law that has a disparate impact on women may constitute discrimination under title VII, the state court held that a facially neutral employment policy that provided no leave time for employees could constitute discrimination against women. ${ }^{96}$ Miller-Wohl's policy provided no leave for new employees like Buley. Thus, the court concluded, "[a]lthough the pohicy was facially neutral, it nonetheless subjected pregnant women to job termination on a basis not faced by men. The no-leave policy therefore appears ... to be gender-based discrimination by an employer in violation of Title VII and the PDA."97 Under this reasoming, not only would a state law providing pregnancy-leave be consistent with title VII, but imdeed, an employer's failure to provide such a leave would likely violate the federal statute.

Having reversed the lower court on title VII grounds, the Montana Supreme Court did not directly address the constitutional issue. Despite the fact that the state district court had held that the MMLA violated the equal protection clause, the state supreme court's only mention of the issue was to note im the course of a discussion of another issue that " "under the Equal Protection Clause ... men and women are not treated unequally when pregnancy is the one physical condition given preferential treatment. Rather ... the MMLA places men and women on more equal terms." "98 Whether this brief passage constitutes a constitutional holding is ambignous. The court did not exphicitly accept or reject the Geduldig precedent ${ }^{99}$ and thus, left the equal protection issue hanging. Nevertheless, the case provided an opportunity for the Supreme Court to overrule Geduldig if it desired to do so.

The employer appealed the state court decision to the Supreme

\footnotetext{
96. Id. at 256,692 P.2d at 1252 .

97. Id.

98. Id. at 259, 692 P.2d at 1254 (quoting Miller-Wohl Co. v. Comm'r of Labor \& Indus., 515
}

F. Supp. 1264, 1266 (D. Mont. 1981)).

99. The state court did not comment on Geduldig, but the federal opinion quoted in the state decision cites Geduldig for the proposition that a law that singles out pregnancy is not necessarily a sex-based classification. 515 F. Supp. at 1266 (quoted in 214 Mont. at 259, 692 P.2d at 1254).

Neither the vacated federal opinion nor the state supreme court opinion indicate that the employer challenged the MMLA on state constitutional grounds. The Montana state constitution prohibits denial of "equal protection of the laws" and also explicitly bars discrimination on the basis of sex. MONT. CONST. art. II, $\S 4$. Had the einployer challenged the Montana statute under these provisions, the state court would not have been bound by Geduldig for the purposes of the state constitutional claim. The court could have analyzed the statute as a sex-based classification. Also, some states with an equal rights amendment in their constitution have required more searching scrutiny of sex-based classifications. See Comment, Equal Rights Provisions: The Experience Under State Constitutions, 65 CaLIF. L. Rev. 1086 (1977). The Montana high court, however, has accorded the same level of scrutiny to sex-based classifications challenged under its state constitution as those challenged under the federal constitution. See, e.g., State v. Craig, 169 Mont. 150, 545 P.2d 649 (1976). Thus, challenging the statute under the state constitution probably would not have affected the state court's decision in Miller-Woht. 
Court. Because the case fell within the mandatory appellate jurisdiction of the Court, the Court was forced to take some action on the case, even if only to avoid a substantive ruling. ${ }^{100}$ The route the Court chose was to hear and decide Cal Fed instead.

\section{B. Cal Fed}

At the same time that Miller-Wohl was on appeal before the Supreme Court, the Court used its discretion under its certiorari jurisdiction to hear California Federal Savings \& Loan Association v. Guerra ${ }^{101}$ which raised the single issue of whether title VII preempts a pregnancyleave state statute. The case arose when California Federal Savings and Loan Association (Cal Fed), a bank, challenged the California statute that provides employment leave for pregnancy. ${ }^{102} \mathrm{Cal}$ Fed had adopted a facially neutral leave pohicy that permitted employees to take temporary leaves of absence for a variety of reasons but that did not guarantee a job upon their return. Applying this pohicy, the bank had refused to reinstate Lillian Garland, a receptionist, when she first returned from a pregnancy leave. Garland filed a complaint with the California Department of Fair Employment and Housing, and the Department issued an administrative accusation charging $\mathrm{Cal}$ Fed with violating the California law. The bank, jomed by the Merchants and Manufacturers Association and the California Chamber of Commerce, then filed suit im federal court to challenge the state law on the single ground that title VII preempted the state law. ${ }^{103}$

The United States district court held that California's "preferential treatment of females disabled by pregnancy, childbirth or related medical conditions" conflicted with title VII. ${ }^{104}$ The Ninth Circuit reversed, stating that the district court's holding amounted to a conclusion that the California law "discriminates agamst men on the basis of preguancy," a conclusion that "defies common sense." 105 The Nimth Circuit held that

100. Under federal statute at that time, when the final judgment of the highest court of a state upheld a state law where its validity had been challenged "on the ground of its being repugnant to the Constitution, treaties or laws of the United States," Suprenue Court review of the decision on appeal was mandatory. 28 U.S.C. $\$ 1257$ (1982). The Court's mandatory appellate jurisdiction, however, has been largely eliminated by Congressional Act. Act of June 27, 1988, Pub. L. No. 100352,102 Stat. 662 . For a discussion of the actions the court could have taken and the course it chose instead, see infra note 124 and accompanying text.

101. 107 S. Ct. 683 (1987).

102. CAL. Gov't CODE $\S 12945(\mathrm{~b})(2)$ (West 1980). For full text and discussion of the state law, see supra notes 18-20 and accoinpanying text.

103. The account of the facts is based on the Suprene Court account. See 107 U.S. at 687-88. For an explanation of the developments that allowed the federal courts to take jurisdiction in $\mathrm{Cal}$ Fed, see Kay, supra note 75, at 14 n.77.

104. 33 Empl. Prac. Dec. (CCH) para. 34,227 , at 32,782 (C.D. Cal. 1984).

105. 758 F.2d 390, 393 (9th Cir. 1985). 
the California statute was permissible because "[t]he PDA does not require states to ignore pregnancy. It requires that women be treated equally."106 The employer appealed, and the Supreme Court granted certiorari to decide the preemption question. ${ }^{107}$

\section{The Debate About the Meaning of Equality}

Feminists were divided in their responses to Miller-Whol and $\mathrm{Cal}$ Fed, resulting in feminists submitting amicus briefs to the Supreme Court on both sides of the cases. ${ }^{108}$ Principally, feminists disagreed over whether they should countenance legal distinctions based on pregnancy if those distinctions worked to the iminediate advantage of women. Havmg fought for gender-blind and pregnancy-blind work rules, could femimists argue that pregnancy is deserving of accommodation as long as this recognition does not disadvantage women? Can legal policy acknowledge biological difference without recreating the rationale for tlie subordimation of women? Different answers to these questions gave rise to what one side labeled the "equal treatment/special treatment" debate. ${ }^{109}$

On one side of the debate were those argning for "equal treatment,"

106. Id. at 396.

107. 474 U.S. 1049 (1986).

108. For examples of feminists arguing that title VII preempted the California statute unless comparable leave were extended to all employees for temporary disability, see Brief for the National Organization for Women; NOW Legal Defense \& Education Fund; National Bar Association; Women's Lawyers' Division, Washington Area Chapter; National Women's Law Center; Women's Law Project; and Women's Legal Defense Fund, Amici Curiae, Cal Fed, 107 S. Ct. 683 (1987) (No. 85-494) [hereinafter Cal Fed Brief for NOW]; Brief for the American Civil Liberties Union; the League of Women Voters of the United States; the League of Woinen Voters of California; the National Women's Political Caucus; and the Coal Employment Project, Amici Curiae, Cal Fed, 107 S. Ct. 683 (1987) (No. 85-494) [hereinafter Cal Fed Brief for ACLU]; Motion for Leave to File Amici Curiae Brief and Brief Concerning Jurisdictional Statenient for ACLU; ACLU of Montana; League of Women Voters of the United States; League of Women Voters of Montana; NOW; NOW Legal Defense and Education Fund; and Women's Legal Defense Fund, Amici Curiae, Miller-Wohl, 107 S. Ct. 919 (1987) (No. 84-1545) [hereinafter Miller-Wohl Brief for ACLU].

For examples of feminists arguing that the California statute was consistent with title VII, see Brief for Equal Rights Advocates; the California Teachers Association; the Northwest Women's Law Center; the San Francisco Women Lawyers Alhance; Amici Curiae, Cal Fed, 107 S. Ct. 683 (1987) (No. 85-494) [hereinafter Cal Fed Brief for Equal Rights Advocates]; Brief for the Coalition for Reproductive Equality in the Workplace (CREW); Betty Friedan; International Ladies' Garnent Workers' Union, AFL-CIO; 9 To 5, National Association of Working Women; Planned Parenthood Federation of America, Inc., et al., Amici Curiae, Cal Fed, 107 S. Ct. 683 (1987) (No. 85-494) [hereinafter Cal Fed Brief for CREW]; Brief for California Women Lawyers; Childcare Law Center; Jessica McDowell; Lawyers Committee for Urban Affairs; Mexican American Legal Defense and Education Fund; Women Lawyers' Association of Los Angeles; Woinen Lawyers of Sacramento, Amici Curiae, Cal Fed, 107 S. Ct. 683 (1987) (No. 85-494).

109. The proponents of identical treatment claimed to advocate "equal treatnient" and characterized feminists supporting the pregnancy-leave statutes as advocating "special treatment." See, e.g., Williams, supra note 75, at 325-28 (proponent of equal treatment describing the debate). This label reflects the bias of those who equate identical trcatment with "equal treatment" and does not accurately portray the feminist justifications for pregnancy-leave statutes. 
in effect identical treatment of the sexes without regard for biological difference. ${ }^{110}$ These advocates, including prominent women's organizations such as the National Organization for Women and the League of Women Voters, interpreted the PDA's prohibition against pregnancy discrimination as prohibiting laws that singled out pregnancy. ${ }^{111}$ Under this reading, title VII, as amended by the PDA, preempts state laws such as those in California and Montana that condition employment benefits on pregnancy. Similarly, these laws violate equal protection. ${ }^{112}$

The basic argument in favor of this position was that gender equality requires pregnancy-blindness. ${ }^{113}$ Legal rules based explicitly on pregnancy, even advantageous rules, would reinforce stereotypes of woinen as primarily childbearers and childrearers. Furthermore, because providing an extra benefit to pregnant workers might make them more costly employees, such laws could backfire on women by "protecting" them out of jobs as had protective legislation earlier in the century. ${ }^{114}$ Consequently, the point of the PDA was not just to prevent disadvantageous treatment of pregnancy but to prevent any singling out of pregnancy. To comply with the PDA, then, employment pohcy should treat pregnancy just like other disabilities. The analogy of pregnancy to disability was sustained by a "functional" analysis of pregnancy; like other disabilities, pregnancy affects an employee's capacity to work and hence economic security. ${ }^{115}$

Although this interpretation would eliminate pregnaricy as a legal justification for constraining women's economic opportunities, as a practical matter it could result in women having no safeguard against losing their jobs if they become disabled by pregnancy or if they need more time to recuperate from childbirth than an employer allows. This lack of job security is especially likely to hurt women in jobs with few fringe benefits, women who may already be economically vulnerable. As a remedy to this problem, the equal treatment proponents advocated requiring employers to provide soine leave for all disabihities, not just pregnancy. ${ }^{116}$

110. See, e.g., Williams, supra note 75; Taub, From Parental Leaves to Nurturing Leaves, 13 N.Y.U. Rev. L. \& Soc. Change 381, $381-84$ (1984-85).

111. See Cal Fed Brief for NOW, supra note 108, at 13-15; Cal Fed Brief for ACLU, supra note 108, at 36-39; Miller-Wohl Brief for ACLU, supra note 108, at 12-23.

112. Although the amicus briefs did not address the equal protection issue, one of the main proponents of identical treatment applies her perspective to the equal protection clause in addition to title VII. See Williams, supra note 75, at 331-32.

113. For the arguments that follow, see, e.g., Williams, supra note 75; Taub, supra note 110.

114. E.g., Williams, supra note 75, at 371 \& n.182; Miller-Wohl Brief for ACLU, supra note 108 , at 14-15. For a discussion of the way reproductive capacity was used historically to justify women's economic subordination, see supra note 79.

115. Williams, supra note 75 , at $355-57$ \& n.121.

116. See Cal Fed Brief for NOW, supra note 108, at 20-31; Cal Fed Brief for ACLU, supra note 108, at 48-63; Miller-Wohl Brief for ACLU, supra note 108, at 32-45. 
On the other side of the debate were feminists who argued that a concept of gender equality must take some account of biological difference. ${ }^{17}$ Because only women can become pregnant, the way to provide both women and men with an equal opportunity for job security while having children is to provide women with a temporary leave of absence for childbirth and pregnancy-related physiological problems. ${ }^{118}$ Under this view, a leave provision narrowly drawn to cover only disability resulting from pregnancy or childbirth is sufficiently justified to survive intermediate scrutiny under equal protection. Similarly, this approach interprets the PDA as prohibiting disadvantageous treatment of women on the basis of pregnancy, not as prohibiting all legal distinctions based on pregnancy. If the pregnancy classification serves equality, then it is not preempted by title VII. On the contrary, failure to provide a leave adversely affects women, thus potentially violating title VII. ${ }^{119}$

Another argument in support of pregnancy-leave statutes was that they benefit both women and men. ${ }^{120}$ By enabling both fathers and mothers to combine procreation and employment, employment leave for pregnancy serves both women's and men's right of procreation. To analogize pregnancy to disability, as the proponents of identical treatment would do, fails to recognize "the basic commonality of procreation as a human endeavor involving both women and men."121

As the debate reflects, enforcement of title VII's prohibition against pregnancy discrimmation and the fourteenth amendment's guarantee of equal protection implicitly requires adopting soine analysis of the meaning of equality. Thus, Miller-Wohl and Cal Fed presented the Court with the challenge of adopting a coherent analysis of the relationship between biological difference and gender equality to guide preguancy jurisprudence.

\section{The Court's Decision}

Despite the need for a coherent equality doctrine, the Court failed to provide a federally binding defintion of the meaning of the constitutional guarantee of equal protection or of title VII's prohibition against pregnancy discrimination. Instead, the Court limited its holding in Cal Fed

117. See, e.g., Cal Fed Brief for Equal Rights Advocates, supra note 108; Cal Fed Brief for CREW, supra note 108 .

118. Cal Fed Brief for Equal Rights Advocates, supra note 117, at 5-9; Kay, supra note 75.

119. For a persuasive argument that failure to provide pregnancy leave has a disparate impact on women, see Note, Employment Equality Under the Pregnancy Discrimination Act of 1978, 94 YALE L.J. 929, 940-56 (1985).

120. See Cal Fed Brief for CREW, supra note 108, at 37.

121. Littleton, Reconstructing Sexual Equality, 75 CALIF. L. REv. 1279, 1299 (1987) (author of amicus brief for CREW explaining position taken in brief). 
to a narrow interpretation of the preeinptive scope of title VII. ${ }^{122}$ The Court subsequently vacated the Montana Supreme Court judgment in Miller-Wohl and remanded the case to the state court "for further consideration in hight of" Cal Fed. ${ }^{123}$

By remanding Miller-Wohl, the Court avoided deciding whether state laws that provide pregnancy-based employment benefits are constitutional under equal protection. Although Miller-Wohl was within the Court's mandatory appellate jurisdiction and it raised a potentially dispositive constitutional claim not present in Cal Fed, the Court resisted even the normal course of summary disposition. Instead, the Court's use of its discretion to hear and decide Cal Fed on the single issue of title VII preeinption and its subsequent reinand of Miller-Wohl suggest a deliberate choice to avoid the constitutional issue. ${ }^{124}$ The Court thus inanaged to avoid any ruling on the controversial Geduldig decision, neither affirming nor disaffirming it. Even if not deliberate, the rulings left open the issue of whether a state law that provides employinent leave for pregnancy violates the equal protection clause. ${ }^{125}$

Cal Fed also did not provide any federally bimding substantive standard of equality because the Court framed the holding in terms of title VII's narrow preeinptive scope. Nevertheless, Cal Fed provided a framework for analyzing whether particular treatment of pregnancy proinotes

122. 107 S. Ct. 683 (1987).

123. 107 S. Ct. 919 (1987).

124. Because Miller-Wohl was within the Court's mandatory appellate jurisdiction, the Court did not have discretion to refuse to take the appeal. See supra note 100 and accompanying text. The Court, however, had several choices for disposing of the case. The Court could have ruled on the title VII issue without reaching the constitutional issue. The Court also could have avoided ruling on both the constitutional and statutory issues by summarily disposing of the case.

Summary disposition would have had two immediate effects. First, the Montana decisionwhich contained an expansive application of disparate impact analysis under title VII-would have stood. Second, a summary disposition itself would have had some precedential effect. See Hicks v. Miranda, 422 U.S. 332, 343-44 (1975) (summary disposition of previous case was binding on lower court in different case where both cases involved validity of the same statute). But cf. Mandel v. Bradley, 432 U.S. 173, 176 (1977) (summary actions should be understood as applying established principles rather than as breaking new ground). A summary disposition arguably could have been read as a weak endorsement of Montana's analysis of title VII. It could also have been read as a refusal to abandon the equal protection analysis of Geduldig, although such a conclusion would have been debatable in light of Miller-Wohl's ambiguous treatinent of equal protection. Whether the Supreine Court intentionally avoided summary disposition of the case for these reasons is unclear. But see Brief for the United States as Amicus Curiae at 12, Miller-Wohl, 107 S. Ct. 919 (1987) (No. 84-1545) (suggesting that Miller-Wohl contains "certain complexities and ambiguities that may make it a less convenient vehicle for exploring this issue than ... Cal Fed"). What is clear is that the Court managed to avoid any substantive ruling on the constitutional question by using its discretionary jurisdiction to hear and decide Cal Fed instead. The Court then vacated and reinanded Miller-Wohl with no mention of the constitutional issue. Neither Miller-Wohl nor the state of Montana raised the constitutional issue on reinand. Miller-Wohl, 244 Mont. 1718, 744 P.2d 871 (1987).

125. Geduldig does not directly control because it involved the exclusion, not the provision, of employınent benefits for pregnancy. Geduldig v. Aiello, 417 U.S. 484 (1974). 
or detracts from gender equality. This framework provides guidance and precedent for reforinulating equal protection doctrine in the area of pregnancy discrimination.

Read most narrowly, Cal Fed emphasizes states' rights to define what constitutes discrimination. Six Justices held that title VII neither prohibits nor requires states to provide special treatment of pregnancy as long as the states' actions broadly comport with title VII's goal of equal opporturity. ${ }^{126}$

The Court arrived at this holding by narrowly construing the statutory provisions governing preemption of state law. The plurality noted that title VII explicitly provides that the title does not preempt a state or local law unless the law "purports to require or perimit the doing of any act which would be an unlawful employment practice under [title VII]."127 Furthernnore, a section applicable to all of the Civil Rights Act makes explicit that Congress does not intend to occupy the field and that the Act is not to "be construed as invalidating any provision of State law unless such provision is inconsistent with any of the purposes of this Act."128 According to the Court, these sections "severely linit Title VII's pre-einptive effect" and "reflect[ ] the inportance Congress attached to state antidiscrimination laws in achieving Title VII's goal of equal employinent opportunity." 129 Guided by this statutory language, the plurality considered whether the California scheme "requires or permits employers to violate Title VII" or whether it is "inconsistent with the purposes of the statute." 130 Reasoning that California's provision of pregnancy benefits enhances equality between women and men, the Court found no preemption.

Althougli only four Justices joined in this specific analysis of preemption, Justice Scalia concurred with an even greater enuphasis on the narrow preeniptive scope of title VII. Justice Scalia reasoned that the Court should apply only the preeniption provision of title VII, which displaces only those state laws that " "purpor[t] to require or permit" " an act that would be unlawful under the title. ${ }^{131}$ Characterizing this section as an even "more expansive prohibition of pre-einption" than the additional statutory preemption standard on which the plurality had rehed, Justice Scalia concluded that the California statute "does not

126. 107 S. Ct. 683 (1987). Justice Marshall wrote the plurality opinion, joined by Justice Brennan, Justice Blackmun, and Justice O'Connor. Justice Steveus concurred in part in the opinion and concurred in the judgment. Justice Scalia concurred with a separate opinion. Justice White, joined by Chief Justice Rehnquist and Justice Powell, dissented.

127. 42 U.S.C. $\$ 2000$ e-7 (1982).

128. Id. \& $2000 \mathrm{~h}-4$.

129. $107 \mathrm{~S}$. Ct. at 690.

130. Id. at 691 .

131. Id. at 697 (Scalia, J., concurring) (quoting 42 U.S.C. $§ 2000 \mathrm{e}-7$ (1982)). 
remotely purport to require or permit any refusal to accord federally mandated equal treatment to others similarly situated."132

"Remotely" is strong language in view of the fact that both sides of the case had plausible interpretations of what constitutes gender equality under title VII. Had the three dissenters prevailed in their interpretation of the PDA as requiring pregnancy-blind identical treatment of women and inen, then California's preguancy-based distinction would indeed have "required or permitted" unequal treatment. Scalia, however, treats the case as so clear cut that he does not define "equal treatment" or "similarly situated". If Scalia's underlying premise is that pregnancy leave does not "remotely" affect equal treatment of the similarly situated, his reasoning is coinpatible with the Court's logic in equal protection cases that pregnancy is so distinct from gender that it does not raise questions of equal treatment for woinen and men. If this is the ineaning of Scalia's concurrence, then he reintroduced the logic of Geduldig into title VII, despite the PDA's clear rejection of it.

By not requiring einployment leave for pregnancy-related disability, the Cal Fed Court missed an opportunity to forge a standard of gender equality under title VII. The Court could have reasoned, as had the state court im Miller-Wohl, that gender-neutral leave policies that fail to provide adequate leave for pregnancy have a disparate impact on women and thus violate title VII's proscription against preguancy discrimination. ${ }^{133}$ The Court, however, explicitly declined to reach this issue. ${ }^{134}$ In his dissent, Justice White emphasized that the Court should stay out of the "policy dispute" that the cases had generated. ${ }^{135}$ Instead, the Court should defer to Congressional intent, altlougl, as he admitted, Congressional debate over the PDA did not focus on the issue of preferential treatinent. ${ }^{136}$

Even without mandating a standard of equality, lowever, the majority in $\mathrm{Cal} \mathrm{Fed} \mathrm{developed} \mathrm{a} \mathrm{useful} \mathrm{analysis} \mathrm{of} \mathrm{the} \mathrm{siguificance} \mathrm{of} \mathrm{biological}$ difference for evaluating equality between women and men. The analysis is capable of determining whether particular treatment of pregnancy constitutes equal, nondiscriminatory treatment of women and men. To arrive at its holding that title VII does not preempt the California pregnancy-leave statute, a inajority of Justices agreed that legal accoininodation of biological difference is acceptable but only when it puts women and men on equal footing. Writing for four Justices and joined in the

132. Id. (emphasis added).

133. See supra notes $96-97$ and accompanying text. For a discussion of the disparate impact theory as applied to pregnancy leave, see Note, supra note 119.

134. 107 S. Ct. at 695 n.32.

135. Id. at 700 (White, J., dissenting).

136. Id. at 701-02. 
essential reasoning by Justice Stevens, ${ }^{137}$ Justice Marshall concluded that title VII did not preempt the California statute because the statute is consistent with title VII's goal of achieving equal employment opportumity.

The majority rejected the fornial notion of equahty that would require identical treatment of women and men in all mstances. Instead, the Court examined whether the California law achieved equality in substance. Startimg with the premise that the purpose of title VII is "to achieve equality of employment opportumities and remove barriers that have operated . . . to favor an identifiable group of . . . employees," "138 the Court held that the California statute was consistent with that purpose. The California law promotes equality of opportunity because, '"[b]y 'taking pregnancy into account,' California's pregnancy disabihityleave statute allows women, as well as men, to have families without losing their jobs."139

The Court measured equality by examining outcomes for women and men in the workplace as currently structured. Quoting approvingly from Justice Brennan's dissent in General Electric Co. v. Gilbert, the majority opinion recognized that socially equal " "end products . . . may deinand due consideration of the umiqueness of the "disadvantaged" individuals. A realistic understanding of conditions found in today's labor environınent warrants taking pregnancy into account in fashioning disability pohicies." "140 Similarly, in his concurrence, Stevens also justified the statute as compensating for disadvantage. He reasoned that the California statute represented "preferential treatınent of the disadvantaged class," which was permissible as long as it served the title VII goal of equal employment opportunity. ${ }^{141}$

In essence, the majority defined pregnancy discrimination in ternis of women's concrete experience. The Court imterpreted the PDA's proscription against pregnancy discrimination as prohibiting policies that disadvantage women because of pregnancy. By contrast, policies that provide "preferential treatment" of pregnancy to equalize both sexes' employment opportumities do not constitute discrimination. Discrimination thus consists of more than merely singling out pregnancy; whether a pohicy discriminates depends on how it deals with women's reproductive capacity. Borrowing language from the Court of Appeals' opinion, the

137. Justice Stevens concurred in the judgment and in most parts of the plurality opinion. Except for questioning whether only one or both of the preemption statutory sections apply to the case, Stevens joined in the plurality's substantive analysis of gender equality. See id. at $696 \mathrm{n} .1$.

138. Id. at 693 (quoting Griggs v. Duke Power Co., 401 U.S. 424, 429-30 (1971)).

139. Id. at 694 (quoting General Electric Co. v. Gilbert, 429 U.S. 125, 159 (1976) (Brennan, J., dissenting)).

140. Id.

141. Id. at 696-97 (Stevens, J., concurring). 
Court characterized the PDA as creating "a floor . . . not a ceiling" for pregnancy employment benefits. ${ }^{142}$ The Court read the second clause of the PDA, which specifies that pregnant woinen are to be treated the saine as other persons similarly able or unable to work, as directing only that employers cannot provide fewer benefits to pregnant employees than to other disabled employees. The clause is a pointed criticism of Gilbert, not a prohibition against employers providing more benefits to pregnant employees than to others. ${ }^{143}$

The majority's equality analysis also addressed the fear voiced by some feminists that allowing laws that accommodate woinen would once again create the justification for protective legislation that had served to reinforce woinen's second-class status in the labor inarket. The Court carefully distinguished preferential treatinent designed to give woinen an equal footing in the workplace from past protective legislation that had constrained women's opportunities. Einphasizing that the California statute was "narrowly drawn to cover only the period of actual physical disability," the Court suggested that the PDA would preenpt a state law based on "stereotypical notions about pregnancy and the abilities of pregnant workers." 144

As an alternative reason for upholding the state law, the Court accepted the argnment of the identical-treatinent feminists. The majority reasoned that if title VII were to be interpreted as requiring identical treatınent of all employees, title VII still would not preempt the Califorma law. Employers could coinply with both federal and state law because the California law did not prevent employers from extending the disability leave benefit enjoyed by pregnant employees to all employees. $^{145}$

\section{E. Implications of Cal Fed for Constitutional Analysis}

The reasoning in $\mathrm{Cal} \mathrm{Fed} \mathrm{provides} \mathrm{an} \mathrm{example} \mathrm{of} \mathrm{a} \mathrm{possible} \mathrm{judicial}$ standard for evaluating whether laws involving pregnancy and childbirth treat women and men equally. The Cal Fed decision took the important analytic step of distinguishing between biological difference and social outcoine. Cal Fed implicitly recognized that the way society deals with childbearing, not biological difference in and of itself, determines whether woinen and men are equal. Thus, in evaluating whether a law is consonant with the goal of equality, $\mathrm{Cal} \mathrm{Fed}$ focused on whether the law's treatinent of biological difference promotes social equality. This

142. Id. at 692 (quoting 758 F.2d 390, 396 (9th Cir. 1985)).

143. Id.

144. Id. at 694; see also id. at $691 \mathrm{n} .17$ (Title VII would prohibit states from mandating "special treatment of pregnant workers based on stereotypes.").

145. Id. at 694-95. 
inquiry did not ignore biological difference, but neither did it accept biological difference as a justification for penalizing woinen in the labor inarket. By shifting the focus to the social impact of legal treatınent of biological difference, the Court's analysis was capable of distinguishing between favorable and unfavorable treatınent of pregnancy and between actual disability and stereotypical notions of incapacity.

By shifting the ground conceptually, Cal Fed also increased the disparity between the equal protection and title VII analyses of laws governing employer treatinent of pregnancy and childbirth. Coinpared to the subtle analysis of equality in $\mathrm{Cal} \mathrm{Fed}$, the current constitutional standard established by Geduldig leaves the Court with only a blunt tool for evaluating laws that provide einployinent leave for pregnancy or childbirth. To give equal protection doctrine the analytic sophistication it needs, the Court should revise its equal protection analysis of laws governing einployee pregnancy benefits to reflect $\mathrm{Cal} \mathrm{Fed's} \mathrm{insights} \mathrm{about}$ equality. The reinainder of this Comment recommends specific revisions to inake equal protection doctrine as capable as Cal Fed of discerning permissible and impernissible treatment of pregnancy.

\section{$\mathrm{V}$}

\section{A Revised Constitutional ANalysis of Pregnancy DISCRIMINATION}

Unless the Supreine Court revises equal protection doctrine, childbearing women are potentially deprived of the constitutional guarantee of equal treatment. Existing doctrine, controlled by Geduldig, dictates that laws that make distinctions based on pregnancy are not sexbased classifications. Under the current approach, then, the California, Connecticut, Montana, and Tennessee statutes which provide leave for pregnancy are not sex-based classifications. They are constitutional under the equal protection clause as long as they are rational and are not a pretext for sex discrimination, a standard these laws would almost surely survive.

Equal protection doctrine in its current state provides no basis for distinguishing equal from unequal treatınent. It erroneously assumes that biological difference inherently justifies employment policies that treat women and men differently. This analysis inistakenly focuses on biological difference rather than on the social relationships that have been built on the foundation of biological difference. Geduldig is the clearest articulation of this inistaken analysis and should be overruled.

The Court needs to adopt an equal protection doctrine that is capable of analyzing the impact on gender equality of statutes concerning pregnancy. The revision must be informed by an analysis of the relationship between biological difference and gender equality. This relationship 
should not be oversimplified, either by arguing that accommodating biological difference has so little bearing on gender equality that it is always justified or by arguing that accommodating biological difference so inextricably perpetuates imequality that it is never justified. Instead, equality analysis should recoguize that law can treat biological difference in ways that either promote or detract from equality. Thus, whether a law violates the equal protection clause should not depend simply on whether it differentiates on the basis of pregnancy. Whether the law is constitutional depends on its impact on the social and economic status of women.

Although others have suggested a similar analysis, ${ }^{146}$ the approach suggested here is unique $i m$ that it focuses on the impact of a law without requiring a departure from the established equal protection framework for evaluating gender-based classifications. If the Court were to recognize that laws governing pregnancy do classify by gender, intermediate scrutiny could result im upholding pregnancy-leave statutes that equalize wornen's and men's status and overturning those statutes that do not. Specifically, intermediate scrutiny could distinguish between sex-based classifications that rest on disadvantaging stereotypes and classifications that rest on actual differences in need resulting from wonien's reproductive capacity. Cal Fed demonstrates that the Court is capable of making such distinctions.

The remainder of the Comment develops further a theory of the relationship between biological difference and gender equality, describes the equal protection approach which flows from this theory, and then applies this approach to assess the constitutionality of state laws that provide pregnancy, childbirth, or inaternity leave from einployment.

\section{A. Defining Equality}

Interpretation of the equal protection clause depends on how one defines "equal". As the history of preguancy jurisprudence reflects, equal treatment is susceptible to inore than one definition.

Geduldig reflects one extreme: the view that women who are pregnant and inen need not be treated equally. The biological determinism that underlies this view iguores the crucial fact that the social arrangenients surrounding pregnancy are socially constructed and capable of transformation. The shape and content of these social relationships are not a necessary, inevitable product of biology. By accepting laws based on biological difference as self-justifying, Geduldig merely reinforces existing social relationships. These laws have frequently served historically to reinforce women's subordmate social and economic status, but a biologically determinist view insulates these laws froin judicial scrutiny,

146. See infra notes $155-162$ and accompanying text. 
potentially leaving unequal treatment intact. ${ }^{147}$

The other extreme is the identical-treatment view, positing that equality consists of identical treatment without regard for biological difference. ${ }^{148}$ This view accepts the classic liberal definition of equality and consequently suffers from its limitations. Under classic liberahism, equality means equality of opportunity regardless of individual differences. ${ }^{149}$ Hence, a legal commitment to equality obligates society to provide a woman only an equal opportunity to perform her job; society need not take account of her individual attributes, including her reproductive capacity. Accordingly, as the identical treatment proponents argued in Cal Fed and Miller-Wohl, a woman's fate in a particular job sloould be determined by her individual job performance. Employers should neither prescreen leer out of a job nor give her special dispensation because of pregnancy; they should give benefits to all workers or to none.

The problem with equality of opportumity is its refusal to take account of differences in people's situations. Providing equality of opportunity to people with different or unequal starting points leads to unequal results. ${ }^{150}$ Classic hiberalism recognizes this problem but atternpts to deal with it by elimmating the legal significance that attaches to people's differences. For example, the classic liberal solution to sex discrimination is to prolibit legal distinctions based on sex. Professor Kay has labeled this inodel "assimilatiomist" because "it wisles to iniminize the significance of reproductive differences between inen and women."151 This solution works in most instances because inherent differences in reproductive capacity do not affect woinen's and inen's capacities and abilities.

The classic liberal solution fails, however, when eliminating a legal distinction does not eliminate the difference in actuality. Pregnancy and childbirth are the prime example. No anount of social reconstruction can cliange the fact that women bear children and men do not; even if technology could alter this fact, few proponents of gender equality would advocate changing this inherent biological difference. ${ }^{152}$ Accordingly, policy that ignores pregnancy reinforces existing social arrangeinents. If those social arrangements favor inale biology-as did, for example, the facially neutral leave policies of the einployers in $\mathrm{Cal} \mathrm{Fed}$ and Miller-

147. See supra notes $62-64$ and accompanying text.

148. See supra notes $110-116$ and accompanying text.

149. See Schaar, Equality of Opportunity and Beyond, in ConTEMPorary Political Theory 135,136 (A. de Crespigny \& A. Wertheimer eds. 1970) ("The doctrine [of equality of opportunity] ... asserts that each man should have equal rights and opportunities to develop his own talents and virtues and that there should be equal rewards for equal performances. The formula does not assume the enpirical equality of inen.").

150. Id. at 138.

151. Kay, Models of Equality, 1985 U. ILL. L. REv. 39, 40.

152. But see S. Firestone, The Dialectic of Sex (1970) (advocating research into reproductive technologies to free wolnen from pregnancy and childbirth). 
Wohl-then ignoring biological difference at a policy level estabhishes men as the standard and marginalizes women. The original complainants in Cal Fed and Miller-Wohl lost their jobs when their inale counterparts would not have lost theirs after engaging in precisely the same behavior. Employment laws that uniformly ignore women's reproductive capacity may provide equal treatunent in the abstract but produce inequality in reality. Thus, although the identical treatment view is understandable as a defensive response to the historical use of biological difference as a justification for women's subordination, it does not respond to women's actual needs.

The better solution, one advanced by this Comment, is to develop a judicial standard for gender equality that can distimguish between unnecessary, sex-based distinctions that arise from stereotypes on the one hand, and nonstiginatizing distimctions based on actual, biologically created needs on the other. Recoginition of women's childbearing capacity need not mevitably give rise to subordination; it is theoretically possible to construct different, nondisadvantaging social meanings out of biological difference. As Professor Catherine MacKinnon has argued, biological difference is not itself the cause of social mequality. She writes, "[t] $]$ here is nothing in a difference that dictates inferiority; there is only the society that makes the content of those differences into imferiorities. . .. [I]t is the social meaning attributed to the differences that is at stake and determines the social position of the group, not the differences themselves."153

One possible judicial standard capable of differentiating between permissible and impermissible pregnancy-based distinctions dervives from the "episodic" approach proposed by Professor Herna Hill Kay. ${ }^{154}$ Under this approach, a law may permissibly take into account biological reproductive sex differences in those brief "episodes" when women's childbearing capacity is utilized. Accommodation of biological difference in this view nerely provides women with the same opportunities as men, not "special treatnent." This analysis posits that true equal eniployment opportunity requires recoginition and accommodation of difference at the point when pregnancy or childbirth teniporarily affects women's ability to work. Accordingly, differential treatment would be justified in the short period when a woman is dehvering a child and recuperatimg from delivery or experiencing medical complications in the course of the pregnancy itself. This inodel potentially allays the fears raised by the identical treatment school, as it carefully limits when law may recognize biological difference and thus avoids reinforcing stereotypes that constrain wonien's opportunities.

153. C. Mackinnon, Sexual Harassment of Working Women 140 (1979).

154. Kay, supra note 75 , at 21-28. 
Another possible standard measures equality in terms of equality of result. This model rests on the premise that the current economic structure is not gender neutral. By assuming the male worker is the norm, the structure of work systematically disadvantages women. Insofar as wage levels, job security, frimge benefits, and career advancement are based on full-time uninterrupted work, the structure inherently favors men. Men do not physically need to stop working to bear a child, and under the traditional sexual division of labor, men generally have not taken primary responsibility for childrearing. Under a theory of equality of result, the goal is not to "accommodate" women to a workplace structure that ignores childbearing and childrearing; the goal is to transform the workplace so that it acknowledges and facilitates bearing and raising children. Accordingly, laws providing employment benefits for pregnancy would be evaluated on whether they contributed to or detracted from equalizing women's and men's position in the workplace. Laws that provide job security for women who leave work temporarily to bear a child could be justified as a step toward restructuring the workforce to accoinmodate it to the needs of women as well as those of men.

Feminist legal scholars Catherine MacKinnon ${ }^{155}$ and Sylvia Law ${ }^{156}$ have similarly suggested that the impact on women should be the ineasure of the constitutionality of laws governing pregnancy. Both, however, suggest departures fron the traditional equal protection framework. MacKinnon criticizes the traditional framework of evaluating whether a law treats similarly situated groups alike; she argues that this is the wrong question, as illustrated by the Court's inability to evaluate practices that differentiate on the basis of biological difference. Starting from the premise that existing sex discrimination stenis from male dominance and the subordination of women, she proposes that courts evaluate the constitutionality of sex-based classifications by examining "whether the policy or practice in question integrally contributes to the maintenance of an underclass or a deprived position because of gender status."157

While MacKinnon would use this standard to evaluate all sex-based classifications, Sylvia Law proposes a new equal protection framework only for "laws governing reproductive biology."158 Because these laws "govern ways in which men and women are not similarly situated,"159 she suggests that equal protection analysis of these laws should focus on the impact of the law on gender equality. Under Law's proposed stan-

155. C. MacKinNon, supra note 153.

156. Law, Rethinking Sex and the Constitution, 132 U. PA. L. Rev. 955 (1984).

157. C. MACKinNoN, supra note 153 , at 117.

158. Law, supra note 156 , at 1007.

159. Id. at 1009. 
dard of review, courts would scrutinize "laws governing reproductive biology" by examining whether the law has a "significant impact in perpetuating either the oppression of woinen or culturally imposed sex-role constraints on individual freedoin."160 Although this part reseinbles MacKinnon's approach, Law would additionally require that a law found to have a significant impact be subject to a form of strict scrutiny. Such a law would survive constitutional review only if it could be justified "as the best ineans of serving a compelling state purpose."161 Under her scheine, a law granting pregnancy leave presents a close case; whether such a law oppresses woinen or is supported by a compelling state purpose should be left as a "question of fact and judgment" in a particular case. ${ }^{162}$

Both MacKinnon's and Law's proposals, although compelling, go further than inay be necessary or practically possible. MacKinnon's approach is not practical in the short term. Although her analysis of sex inequatity is intellectually sound, the Court is unlikely to be willing anytime soon to rethink its entire analysis of gender equality in terms of relations of domination. Regardless of its long-term desirability, large numbers of working women need legal protection inore immediately. When einployers challenge pregnancy-based laws, as in Cal Fed and Miller-Wohl, feminist lawyers need to decide whether and what side to argue, and having inade a decision to represent a client, they need persuasive arguinents that have soine chance of acceptance by a court. Furthermore, as Law points out, judges inay not be coinpetent to do the subtle analysis required by MacKiunon's approach. ${ }^{163}$

Although Law's approach is himited to laws governing reproductive biology, the Court inay not be willing to inake even a limited departure froin its traditional equal protection framework. Even if the Court were to accept Law's approach, her analysis inay reinforce the Court's overemphasis of the divide between preguancy-based laws and other sexbased distinctions. Even with a high degree of scrutiny of laws governing reproductive biology, feminists inay not want biological difference to figure so prominently in the Court's doctrime. As she herself argnes, "state control of a woinan's reproductive capacity and exaggeration of the significance of biological difference has historically been central to the oppression of women." 164

This Comment adopts MacKinnon's and Law's focus on the mipact

160. Id. at 1008-09.

161. Id. at 1009.

162. Id. at 1031 .

163. Id. at 1005. Law acknowledges that her approach similarly requires judges to engage in a difficult inquiry but defends it on the grounds that the inquiry is limited only to laws governing reproductive biology. Id. at 1010.

164. Id. at 1008 . 
on women as the measure by which to judge whether a pregnancy-based classification demies equal protection. The approach suggested here, however, would not require the Court to depart from its standard of intermediate scrutiny. Informed by the insights of $\mathrm{Cal} \mathrm{Fed,} \mathrm{the} \mathrm{tradi-}$ tional equal protection analysis of sex-based classifications would be capable of distinguishing between permissible and impermissible pregnancy-related classifications. To trigger this analysis, the Court must first recognize that pregnancy classifications are gender-based classifications.

\section{B. Pregnancy Classifications as Gender Classifications}

Laws affecting pregnancy or childbirth are gender-based laws. Refusing to recoguize this fundamental fact, Geduldig reasoned that a pregnancy classification harms or benefits all "nonpregnant persons," a category that includes women as well as men. ${ }^{165}$ This analysis fails to recognize that society's treatment of pregnancy affects all women.

A pregnancy-based classification is a gender classification for the obvious reason that only women have the capacity to become pregnant. Professor Kay has shown that the Court has neglected to recoguize this fact in its equal protection doctrine because it has selected the wrong universe of similarly situated individuals. ${ }^{166}$ In evaluating the effect of a pregnancy classification, the Court should take as its referent the universe of working people "who have engaged in reproductive behavior." 167 Among this group, a law governing treatment of pregnancy differentiates precisely by sex: of those who procreate, the category of pregnant persons and the category of women overlap one hundred percent. Thus, once the universe is narrowed from all people to all those who engage im reproductive conduct, pregnancy classifications are obviously gender-based.

A social analysis of gender relations leads to the same conclusion. Feminist analysis posits that gender identity is shaped by what one theorist has called the "sex/gender system", defined as the "set of arrangeinents by which the biological raw material of human sex and procreation is shaped by hunian, social intervention and satisfied in a conventional manner."168 From the starting point of biological difference, society constructs a set of arrangements and meanings which define how childbearing and childrearing will take place, who will bear responsibility for raising children, and how much power and status will be asso-

165. Geduldig v. Aiello, 417 U.S. 484,496 n.20 (1974). See supra note 48 and accompanying text.

166. Kay, supra note 75 , at $30-32$.

167. Id. at 30.

168. Rubin, The Traffic in Women: Notes on the "Political Economy" of Sex, in Toward AN ANTHROPOLOGY OF WOMEN 157, 165 (R. Reiter ed. 1975). 
ciated with giving birth or caring for the young. The arrangements are socially constructed, historically variable, and capable of undergoing change. As feminist anthropologists have noted,

[b]iology dictates that women lactate and bear children. But the social and cultural consequences of this fact-that women have been seen as wives, and more particularly as mothers; that their activities have been limited by the responsibilities of child care; that their hives have been defined in terms of reproductive functions ... all of these are human products that ... account for women's secondary status . . . they are subject to, and accessible to, change. ${ }^{169}$

This reasoning suggests that the life experience of woinen and men is shaped by the particular way in which society has treated biological difference. Biological sex difference is socially transformed into gender identity. This social process of transforming biological difference into social identity as woman and man is captured in the term "gender".

How a society deals with biological difference is thus central to gender identity. For example, whether a society attaches prestige and privilege to the tasks of childbearing and childrearing or, conversely, maintains a rigid separation between a high-status pubhc world of work and pohtics and a low-status private world of bearing and raising children will affect each sex's concrete economic opportunities and their subjective sense of theinselves. Laws defining employer treatment of pregnancy reflect and contribute to society's attitudes about the proper roles of women and men. Thus, a law that demies employment benefits to pregnant employees or that provides einployment benefits uniquely for pregnancy affects all women-not only those woinen who becoine pregnant-by providing opportumities or creating barriers and by shaping women's expectations in hight of these opportunities and barriers. Because laws that define society's treatment of women's reproductive capacity go to the heart of gender identity, such laws should be regarded as gender classifications.

The Pregnancy Discrimination Act, by defining pregnancy discrimination as sex discrimination, provides precedent for this social understanding of gender. ${ }^{170}$ Inphicit in passage of the PDA was the recognition that, historically, society has justified women's subordmate social and economic status on the basis of their childbearing capacity. ${ }^{171}$ This history proves the larger theoretical point that the social arrangenients surrounding procreation affect the opportunities available for women and men and define the expectations women and inen have of

169. Rosaldo \& Lamphere, Introduction, in WoMan, Culture, AND SocieTY 1, 14 (M. Rosaldo \& L. Lamphere eds. 1974).

170. 42 U.S.C. $\$ 2000 \mathrm{e}(\mathrm{k})(1972)$. For text, see supra note 8 .

171. See supra notes $\mathbf{7 2 - 7 9}$ and accompanying text. 
themselves. In defining pregnancy-based classifications as gender classifications for the purposes of equal protection, the Court would be doing no more than embracing the analysis it has already accepted in the title VII area.

\section{Intermediate Scrutiny of Pregnancy-Based Classifications}

Once pregnancy classifications are defined as gender classifications, courts should apply intermediate scrutiny, the current standard for evaluating sex-based classifications, ${ }^{172}$ to evaluate laws governing einployer treatment of pregnancy.

Under the logic of equal protection, woinen and inen are similarly situated, and they deserve similar treatınent; the assumption is that, in general, gender should inake no difference in how women and men are treated. This logic can apply as comfortably to pregnancy classifications as to all other sex-based classifications. Women's childbearing capacity should in general make no difference in how woinen and inen are treated. Despite the fact that woinen and men are biologically different, they are similarly situated with respect to existing social relationships and institutions. For exainple, with respect to employinent, both are subject to the same wage laws, working conditions, and economic trends.

Intermediate scrutiny, however, recognizes that differentiating by sex may be justified in soine instances. ${ }^{173}$ Lawinakers inust respond to an equal protection challenge to a sex-based law by justifying the law's different treatment by sex. The issue then, for sex-based classifications generally and for pregnancy-based classifications specifically, is defining when different treatinent is or is not justified.

The standard described and applied in Mississippi University for Women v. Hogan ${ }^{174}$ establishes the criteria for determining what constitutes a vahid justification. Under Hogan, the "party seeking to uphold a statute that classifies individuals on the basis of their gender inust carry

172. See supra note 55 and accompanying text.

173. Because of the flexibility of the intermediate scrutiny standard, it is preferable to strict scrutiny. Strict scrutiny, as developed in race cases, is an exacting standard. Labeling a classification as "suspect" and subjecting it to strict scrutiny appropriately corresponds to the assimilationist goal of minimizing the social relevance of an immutable difference like race. This assimilatiourst stance is appropriate when a classification is never, or virtually never, a legitimate means of accounplishing some government objective. Sex-based classifications, however, may serve a legitimate, nonstigmatizing purpose in those moments when the assimilationist vision of equality does not adequately take account of biological difference. Although, theoretically, courts could uphoid a sex-based law under strict scrutiny if that were the standard adopted, courts occasionally upholding sex-based laws under strict scrutiny might have the negative consequence of eroding the strength of that standard for racial classificatious. An intermediate level of scrutiny, which gives courts grcater latitude in deciding whether to uphold a law, is thus preferable for sex-based classifications.

174. 458 U.S. 718 (1982). 
the burden of showing . . . that the classification serves 'important governmental objectives and that the discriminatory means employed' are "substantially related to the achievement of those objectives." "175 Writing for the majority, Justice O'Connor articulated a strong version of intermediate scrutimy. She inade clear that the burden of proof rests on the party defending the law; courts can not simply supply plausible justifications. ${ }^{176}$ Furthermore, the standard is the same whether the statute allegedly discriminates agamst women or inen. ${ }^{177}$

Most relevant for analyzing pregnancy-based laws is the Court's attention to the social imphications of the challenged law in determining whether the state has met its burden of justification. Without abandoning the intermediate scrutiny standard, Hogan focuses the inquiry on the social impact of the law on women and inen, much like MacKinnon's and Law's focus on whether the law has an oppressive impact on women. ${ }^{178}$

Under Hogan, the test for gender classifications "must be applied free of fixed notions concerming the roles and abilities of males and feinales."179 This dictate applies to both prongs of the test. A government objective that "reflects archaic and stereotypic notions" about women and men is unacceptable as a justification for a gender classification. ${ }^{180}$ Similarly, a direct and substantial relationship between the classification and the objective inust be shown in order "to assure that the validity of a classification is determined through reasoned analysis rather

175. Id. at 724 (quoting Wengler v. Druggists Mut. Ins. Co., 446 U.S. 142, 150 (1980)).

176. Id.; see also H. KaY, SEX-BASEd Discrimination $21 \mathrm{n} .2$ (2d ed. Supp. 1986) (noting Justice $O^{\prime}$ Connor's insistence that the defender of the statute bear the burden of justification).

177. 458 U.S. at 723. See also infra notes 182-183 and accompanying text.

178. The Hogan test rejects laws that rest on stereotypic notions of sex roles that constrain both women and inen, whereas MacKinnon's and Law's impact tests focus on the effect on woinen. The difference in focus reflects a difference in analysis of who is oppressed by a system of gender inequality. Despite this difference, the tests may well produce similar results. Focusing only on the effect on women makes sense if women's subordination is the result of male dominance; if men, both structurally and instrumentally, hold power and privilege at the expense of women, then the equality analysis would focus on whether a practice perpetuates the subordination of women. A test such as Hogan's that focuses on constraints on both women and men is not necessarily inconsistent with MacKinnon's exclusive focus on women, however, because the structure of male dominance ultimately constrains men as well as women to "fixed roles." Regardless of whether men's and women's roles are separate but symmetrical or reflect an asymmetrical power imbalance favoring men, the underlying assumption is that humanity as a whole, men and women, would benefit from eliminatmg the constranits of "archaic and stereotypic" sex roles. A law providing maternal rather than parental leave is an example. While men may benefit from a system under which their work is economically and cnlturally valued and women's work of raising children is not, men also suffer from having less involvement with their children. Presumably, both women and men would gain im the long term if childcare were distributed more equally across gender. Thus, whether the test is designed to identify the oppression of women or the oppression of women and men, the conclusion would be that providing parental leave only to women is oppressive.

179. 458 U.S. at $724-25$.

180. Id. at 725 . 
than througli the neclianical application of traditional, often inaccurate, assumptions about the proper roles of nien and woinen." 181 Thus, internediate scrutiny under Hogan is not satisfied by justifications which reflect socially constructed attitudes which disadvantage woinen or inen.

Hogan also made clear that a sex-based classification that is allegedly intended to compensate for past discrimination will not be uplield if it rests on stereotypic sex roles. The gender classification at issue in Hogan, depending on point of view, compensated wonen for past discrimination or discriminated against inen. The original plaintiff was a man who was denied admission to a state-supported nursing scliool because the scliool statutorily limited its enrollment to women. The state attempted to justify the statute as serving a benign, compensatory purpose for women. ${ }^{182}$ The Court made clear that statutes serving a coinpensatory purpose receive the same degree of scrutiny as statutes that allegedly discriminate against woinen. ${ }^{183}$

To insure that an allegedly compensatory statute does not rest on stereotype, the Court in Hogan set out strict criteria for evaluating an asserted coinpensatory purpose. A gender classification that benefited one sex would be justified only in the limited circumstance where "it intentionally and directly assists meinbers of the sex that is disproportionately burdened." 184 Defending a state law, a state would need to slow that "inembers of the gender benefited by the classification actually suffer a disadvantage related to the classification." 185 The state would also need to demonstrate that the classification is "substantially and directly related to its proposed compensatory objective."186 Reflecting the strengtli of the standard, the Court in Hogan found that the state had failed to justify the all-female nursing school because the school perpetuated the stereotype of nursing as a woinan's job and did not directly relate to the state's objective of coinpensating for discriminatory eniployment barriers because women had not traditionally been excluded froin the field of nursing.

Altlough Hogan did not involve a pregnancy classification, its social analysis of gender can be usefully apphied to differentiate between constitutional and unconstitutional pregnancy-based classifications. The fact that only women bear children may in soine instances justify different treatment but only if such treatment does not hinge on stereotypical notions about women's abilities or constram their opportunities. A per-

\footnotetext{
181. Id. at $725-26$.

182. Id. at 727 .

183. Id. at 728 .

184. Id.

185. Id.

186. Id. at 730.
} 
missible objective would be equalizing both sexes' ability to have children without loss of economic security. Making work structures equally responsive to the needs of woinen and men would be a legitimate purpose that did not rely on stereotypes of women and men.

Pregnancy-leave statutes might also be justified as serving a compensatory purpose; this would depend, however, on whether pregnancybased laws could be characterized as coinpensatory in the first place. One might argue that previous cases in which a state has tried to justify a benign classification as coinpensating woinen are distinguishable because they coinpensated for past economic discrimination against woinen. ${ }^{187}$ Presuinably, im these cases the past economic practice has ceased, and hence the need for conipensation was teniporary. ${ }^{188}$ Laws providing pregnancy benefits derive from an immutable biological difference; thus, such laws have no limiting principle insofar as they cannot be said to be coinpensating ouly for a temporary, historically specific distinction.

The stronger arguinent, however, is that the compensatory purpose cases do apply to pregnancy-based laws because what is at issue is the economic treatnent of reproductive difference. The past structure of work has put women at an economic disadvantage because of their reproductive capacity, and this structure can be changed. Thus, laws that provide einployment leave for pregnancy and childbirth might be justified as coinpensating wonien for a work structure that has not and does not accommodate women's needs. Justice Stevens' concurrence in Cal Fed rehes on similar reasoning; he justified the Califorina law as providing preferential treatinent of a disadvantaged class. ${ }^{189}$

In addition to the law serving an objective that is not based on stereotypes, the means adopted to achieve the law's purpose should be narrowly tailored so as to avoid perpetuating the stereotype of woinen's role as primarily one of childbearer and mother. Professor Kay's "episodic" analysis suggests which pregnancy-based classifications would meet this standard. ${ }^{190}$ Laws that take account of biological difference only during the brief episodes when wonien have unique physical needs arising from pregnancy and childbirth probably would survive intermediate scrutiny. Justifications based on physical need are least likely to rest on stereotypi-

187. See, e.g., Califano v. Webster, 430 U.S. 313 (1977) (different formulas for women and men for computing Social Security benefits upheld as constitutional because they compensated for economic disabilities suffered by women); Kahn v. Shevin, 416 U.S. 351 (1974) (statute providing property-tax exemption for widows but not widowers justified as compensating for past economic discrimination against women).

188. See, e.g., Califano, 430 U.S. at 314 (gender classification in Social Security scheme at issue had, by the time of the decision, been amended by Congress to be gender-neutral).

189. See Califorma Fed. Sav. \& Loan Ass'n v. Guerra, 479 U.S. 272, 294-95 (1987) (Stevens, J., concurring).

190. See supra note 154 and accompanying text. 
cal notions of women and are most likely to advantage rather than disadvantage women. In these circumstances, distinctions based on women's reproductive capacity would pass muster under intermediate scrutiny. Nevertheless, although biological difference would sometimes suffice as a justification, it would not automatically or inherently justify different treatment. Under intermediate scrutiny, a court could uphold a law that differentiates on the basis of reproductive difference only if the law did not perpetuate gender stereotypes. A law that disadvantaged women would not survive scrutiny.

Although not an equal protection case, Cal Fed demonstrates that courts are capable of developing and administering a judicial standard that distinguishes between treatment of pregnancy that equalizes outcomes for women and men and treatment that perpetuates stereotypes about pregnant employees' abilities and about women's proper role. In Cal Fed, the Court emphasized that the California pregnancy-leave statute served the goal of equahty because it enabled "women, as well as men, to have families without losing their jobs."191 By emphasizing that the state law was narrowly tailored to provide leave only for actual disability, the Court imphed that biological difference would be relevant only under limited circumstances. ${ }^{192}$

Cal Fed's reasoning suggests the kinds of factors courts should take into account when evaluating whether a law survives interinediate scrutiny. ${ }^{193}$ To deternnine whether a pregnancy-based law is based on archaic and fixed notions of sex roles, courts should examine such factors as what purpose the law is intended to serve, how closely the law is tied to physical-as opposed to culturally-based-differences between women and men, and what impact the law has on women's economic opportunities. The law would be unconstitutional if it rested on stereotypical notions about pregnancy, constrained women's opportunities, limited their choices about whether and how to combine work and procreation, or accorded women a secondary status in the labor force because of their reproductive capacity.

This suggested approach would recognize biological difference without drawing any foregone conclusion based on that difference. Michael $M$., the case challenging the validity of the California statutory rape law, is instructive. ${ }^{194}$ In his concurrence, Justice Stewart wrote that "in certain narrow circumstances men and women are not similarly situated; in these circumstances a gender classification based on clear differences

191. California Fed. Sav. \& Loan Ass'n v. Guerra, 107 S. Ct. 683, 694 (1987).

192. See id.

193. See supra text accompanying notes 137-144.

194. Michael M. v. Superior Court, 450 U.S. 464 (1981); see supra notes 58.64 and accompanying text. 
between the sexes is not invidious, and a legislative classification realistically based upon those differences is not unconstitutional." ${ }^{195}$ The approach suggested in this Cominent rests on a similar argument but with one important qualification: The fact that women and inen are biologically different does not foreclose equal protection analysis. Courts should begin by assuming that women and men are similarly situated and deserve similar treatment regardless of biological difference. Woinen's childbearing capacity does not autornatically lead to the conclusion that women and men are "not similarly situated." Rather, women's childbearing capacity is potentially relevant only as a possible, far from automatic, justification for treatimg women and inen differently. That women and inen are "not similarly situated" is a conclusion, not a preinise, and furnishes a legitimate basis for different treatment under the law only when biological difference results in actual differences in their physical needs.

Another flaw in Stewart's opimion was that he apphied this reasoning incorrectly-erroneously reading the social stereotypes of woinen and men embodied in the law as necessitated by biology. ${ }^{196}$ This error refiects the danger in ever allowing courts to recognize biological difference. Nevertheless, this danger can be averted by using the reasoning in $\mathrm{Cal} \mathrm{Fed} \mathrm{to} \mathrm{distinguish} \mathrm{between} \mathrm{pregnancy-based} \mathrm{laws} \mathrm{that} \mathrm{reinforce} \mathrm{ste-}$ reotypes and laws that contribute to equality.

In short, Hogan and $\mathrm{Cal} \mathrm{Fed} \mathrm{provide} \mathrm{the} \mathrm{Court} \mathrm{with} \mathrm{ample} \mathrm{prece-}$ dent for revising its analysis of whether laws governing employer treatinent of pregnancy deny equal protection. Applying intermediate scrutiny as elucidated in Hogan, a state would bear a fairly heavy burden in justifying mandatory employment leave for pregnancy. In justifying the law as compensating women for past discrimination or as serving a noncompensatory objective, the state could not rely on stereotypic views of women's roles or justify overly broad rules that might disadvantage woinen. Cal Fed suggests the factors courts should use in evaluating whether the justification rehes on stereotypes or equalizes woinen's and inen's opportumities by accominodating difference in physiological needs.

Although the intermediate standard of review would not be satisfled easily, it also would not create an insurmountable burden. Under the approach outlined here, pregnancy-based laws would survive scrutiny if they were narrowly drawn to equalize the econoinic consequences for woinen and men of women's childbearing capacity.

195. 450 U.S. at 478.

196. See $i d$. at $479-80$. 


\section{Equal Protection Analysis of State Laws Providing Pregnancy- Related Leave From Employment}

The equal protection analysis proposed in this Comment offers the judiciary a tool capable of making the subtle distinctions between permissible and impermissible pregnancy-based classifications. The remainder of this comment uses the suggested approach to analyze the Califorma, Connecticut, Tennessee, and Montana laws that provide employment leave exclusively for woinen.

Under the proposed analysis, the Califorma statute that provides up to four inonths leave for disability resulting from pregnancy, childbirth, or related medical conditions ${ }^{197}$ would be constitutional under equal protection. Because the law classifies on the basis of pregnancy and childbirth, it should be recognized as a gender-based classification. ${ }^{198}$ In response to an equal protection challenge, California would bear the burden of demonstrating first, that the law served an important government objective and second, that the classification was substantially related to achieving that objective. ${ }^{199}$

The objective of the Califorma statute is to ensure that woinen "will not lose their jobs on account of pregnancy disability."200 This objective recognizes that pregnancy and childbirth nay temporarily require a woman to stop working at a job. This objective reflects woinen's actual need arising from biological changes; thus, the objective serves women's interests rather than reinforcing a stereotype.

The objective also could be characterized as coinpensating woinen for a workplace that inakes no allowance for childbirth. The California statute benefits pregnant and childbearing woinen, precisely those who suffer a disadvantage in the workplace that does not allow for pregnancy disability. The statute ineets the test for benign classifications by benefiting the ineinbers of the gender who "actually suffer a disadvantage related to the classification."201

The statute also satisfies the second prong of the equal protection analysis because it is substantially related to achieving the asserted objective. As the Court discussed in Cal Fed, the law allows a woman to take a leave only so long as she is actually disabled. ${ }^{202}$ Thus, the law corresponds precisely to the moment when biological difference creates a genuine difference in physical need between woinen and men. The law does

197. For text and discussion of the California statute, see supra notes 18-20 and accompanying text.

198. See supra notes $165-171$ and accompanying text.

199. See supra note 175 and accompanying text.

200. California Fed. Sav. \& Loan Ass'n v. Guerra, 107 S. Ct. 683, 694 (1987).

201. Mississippi Univ. for Women v. Hogan, 458 U.S. 718, 728 (1982).

202. 107 S. Ct. at 694. 
not assume that a woman necessarily is unable to work because of pregnancy, as the leave is available only upon actual disability and even then, the leave is at the woman's option. Because the law closely ties the benefit to disability, it does not rely on broad assumptions about the proper role of women, such as the assumption that a woman is better able than a man to care for a child. ${ }^{203}$

For the same reasons, the Connecticut statute providing for reasonable leave from employment for "disability resulting from ... pregnancy"204 is constitutional under the equal protection clause. Connecticut also has acknowledged the difference between physical needs and cultural norms by passing the Family Leave Act for state employees which allows the father or mother to take a leave to care for a new child. ${ }^{205}$ That women bear children is a physical fact; that they have been the primary parents is a cultural norm susceptible of change. Connecticut's scheme appropriately provides gender-specific leave for pregnancy disability and gender-neutral leave for caretaking.

The previous version of Tennessee's maternity leave, giving women tinne to "bond" with a new child, provides the counterexample. ${ }^{206}$ Even if Geduldig is not overruled, such a statute would be subject to intermediate scrutiny because it classifies on its face by gender. Nevertheless, under existing precedent, the Court might have upheld the maternity leave because of the Court's tendency to accept women's childbearing capacity as a justification for gender-based classifications. Under the analysis proposed in this Comment, however, a law giving women-but not men - time to bond with a newly born or newly adopted child would clearly be unconstitutional.

The government objective of the former Telmessee statute was to "promote and encourage bonding between a feinale employee and her newly born or adopted child." 207 The establishment of a parent-child bond is imdoubtedly an miportant objective, but this objective fails the

203. Similarly, the Iowa statute closely ties employment leave for pregnancy to disability. It provides that, absent a sufficient employer policy,

the employer of the pregnant employee shall not refuse to grant to the employee who is

disabled by the pregnancy a leave of absenee if the leave of absenee is for the period that

the employee is disabled because of the employee's pregnancy, childbirth, or related medical conditions, or for eight weeks, whichever is less.

IowA CODE ANN. § 601A.6.2.e (West 1988). Because the means substantially relate to the government's interest in preventing discrimination against pregnant employees, the statute is constitutional.

204. For text and discussion of the Connecticut pregnancy-leave statute, see supra note 33 and accompanying text.

205. For text and discussion of the Comieeticut family-leave statute, see supra notes 34-35 and accompanying text.

206. For text and discussion of the former Tennessee Maternity Leave Act, see supra notes 2124 and accompanying text.

207. TENN. CoDE ANN. § 50-1-502(c) (Supp. 1987) (amended by TENN. Code ANN. § 4-21408 (Supp. 1988)). 
first prong of intermediate scrutiny because providing an opportunity for bonding only to women reflects the "fixed notion" that mother-child bonding is more important or appropriate than father-child bonding. Similarly, a state would have difficulty defending such a law as serving a compensatory objective, as such an objective must benefit the burdened class. As both father and mother have the same need to bond with a new child, both women and men are burdened by workplaces that provide no parental leave. By singling out woinen, the former statute reinforced the stereotypical role of women as primary parent. Like the nursing school statute disapproved in Hogan, the law reinforced existing inequality.

The former Tennessee law also made no attempt to tie maternity leave to biological necessity. Only one section-allowing feinale einployees with medical emergencies to take inaternity leave without noticeseemed connected to biological need steinming from pregnancy or childbirth. ${ }^{208}$ Thus, the law's provision of inaternity leave to women to bond with a child exemplified "the mechanical application of traditional, often maccurate, assumptions about the proper roles of inen and women," exactly the flaw that intermediate scrutiny is intended to expose. ${ }^{209}$ As the law stood, it was unconstitutional.

The aniendments to the Tennessee statute ${ }^{210}$ make the question of its constitutionality a closer one. The statute as ainended entitles woinen to employment leave for "pregnancy, childbirth, and nursing."211 Cynically, one might argne that changing the stated purpose should not salvage a law if the effect of the statute is exactly the saine; what is the difference if a woman takes a leave ostensibly to bond with her child or to nurse the child? The cynicisin is justified if the legislature intended merely to save the statute without narrowing the leave to correspond more precisely to the period of physical need.

The objective of the statute on its face is not clear, but even if the objective were, as im California, to enable woinen to bear children without loss of job security, the ineans are impermissibly broad. By allowing leave for nursing, the statute reinforces the cultural pattern that women—but not men-deserve time off from work to nurture a newborn

208. TenN. CODE ANN. § 50-1-501(b)(2) (Supp. 1987).

209. Mississippi Univ. for Women v. Hogan, 458 U.S. 718, 726 (1982). The Massachusetts maternity leave provision has a similar problem. It provides up to eight weeks leave for full-time female employees "for the purpose of giving birth or for adopting a child under three years of age." MASS. GEN. LAWS. ANN. ch. 149, § 105D (West 1988). Although providing leave to women for childbirth corresponds to women's physical needs, providing leave only for women who have adopted a child reinforces the stereotype of the woman as primary parent. As no justification but this stereotype exists for not providing gender-neutral leave to care for an adopted child, this part of the provision would be unconstitutional.

210. For text and discussion of the amended Tennessee statute, see supra notes 25-27 and accompanying text.

211. TENN. CODE ANN. § 4-21-408(a) (Supp. 1988). 
child. Although lactation obviously is a biological capacity specific to women, it is only one of the many aspects of caring for a newborn child. Certainly women are justified in wanting to be home to nurse a child, but men's claim to paternity leave to do the many tasks, aside from nursing, of caring for a child are also legitimate. To privilege women because of their capacity to nurse implicitly assumes that it is more appropriate for women than for men to care for children, at least newborns. Thus, the nursing provision does not substantially relate to equalizing women's and men's status but instead reflects traditional assumptions about the proper roles of women and men. ${ }^{212}$ Thus, the equal protection analysis suggested by this Comment would mvalidate the nursing provision of the current Tennessee statute.

Labeling nursing leave unconstitutional seems harsl1 because ideally women should have the option of caring for a newborn, including nursing, without permanently losing their jobs. However, once we remove the cultural expectation that women are more capable than men of caring for children, depriving men of the option of caring for a new child seeins equally harsh. The constitutional solution to these probleins is to provide gender-neutral parental leave, allowing both women and men the option of nurturing a newly born or newly adopted child. Ideally, einployment policy should provide pregnancy leave to women as well as parental leave to both men and woinen. Statutes that provide employment leave only for woinen should be restricted to physical needs stemming froin pregnancy so as not to perpetuate gender inequality.

Aside from the nursing provision, the amended Teunessee statute is probleinatic because it fails to condition pregnancy leave specifically on disability. The Montana statute suffers from a similar problem. Whether broad wording renders these laws unconstitutional would depend on the construction of the particular statute. The Tennessee statute provides a leave "where applicable," a phrase which could be construed to limit the leave to periods of mability to work. ${ }^{213}$

In the case of the Montana law, ${ }^{214}$ the asserted government objective-providing both woinen and men the opportumity to procreate and liave a family witlout sacrificing job security- ${ }^{215}$ serves an important purpose without perpetuating stereotypic notions about women's roles. The means adopted, however, potentially could reinforce the stereotypical view that pregnancy, even when trouble-free, disables a woman from

212. For a discussion of why women's lactating capacity does not justify gender-based classifications, see Law, supra note 156, at 1033-34.

213. TenN. Code ANN. § 4-21-408(a) (Supp. 1988).

214. For text and discussion of the Montana statute, see notes 28-32 and accompanying text.

215. Miller-Wohl Co. v. Comm'r of Labor \& Indus., 515 F.Supp 1264, 1266-67 (D. Mont. 1981). 
working. Thus, its constitutionality might hinge on whether statutory construction negates this implication. An employer is required to provide a "reasonable" leave, ${ }^{216}$ a qualification which could constrain a woman to take pregnancy leave only when she physically needs it. Imphicitly rejecting the notion that pregnant women are a workforce liability, another subsection of the statute forbids an employer from firing a woman because of pregnancy. ${ }^{217}$ Additionally, an employer may not require a mandatory maternity leave "for an unreasonable length of time." 218 This provision cuts both ways on the question of reinforcing stereotype. On the one hand, it codifies the Court's decision in LaFleur, ${ }^{219}$ prohibitimg employers from forcing pregnant women off the job. On the other hand, it gives employers leeway to force women to take some maternity leave, a provision that may disadvantage women who want to work and may reinforce the notion of pregnant women as incapable of working. The statute is a borderline case because the classification is not as narrowly drawn as it could be. If narrowly construed to provide job security for women who need pregnancy leave for actual pregnancy disability and childbirth, the statute would be constitutional.

\section{VI \\ CONCLUSION}

The now pernianent presence of women in the workforce has led to legislative initiatives governing employers' treatment of employees who become pregnant. These state laws have a major impact on women's hives. Some of these laws begin to alter the workplace to accommodate women's needs, allowing wonien as well as men to have children without the threat of losimg their jobs. Other laws potentially perpetuate gender imequality by reinforcing, in practice and attitude, the view of women as primary parent; such laws undermine women's credibility as serious labor force participants and reduce men's significance as parents.

If these laws are challenged, courts need coherent doctrine to guide them im evaluatimg whether the laws promote or hinder gender equality. A coherent doctrine also would help legislators fashion pregnancy-leave and parental-leave statutes that result in greater gender equatity. The Supreme Court should provide this guidance by revising its equal protection analysis of laws governing employment benefits for pregnancy. By overruling Geduldig and extending its $\mathrm{Cal} F \mathrm{Fe}$ reasoning to equal protec-

216. MONT. CODE ANN. § 49-2-310(2) (1987).

217. Id. § 49-2-310(1).

218. Id. § 49-2-310(4).

219. Cleveland Bd. of Educ. v. LaFleur, 414 U.S. 632 (1974); see supra note 38 and accompanying text. 
tion doctrine, the Court could make the constitutional promise of equal protection a reality for working women and men. 
. 